\title{
Visual Management in Highways Construction and Maintenance in England
}

\begin{abstract}
Purpose

The purpose of this paper is to investigate the current Visual Management practices in highways construction projects in England.

Design/methodology/approach

Following a comprehensive literature review, the research topic was investigated by using five case studies and focus groups.

\section{Findings}

The main findings are (i) the current implementation of VM is limited, particularly on the construction field, (ii) there are some identified points (suggestions) that require attention to disseminate and advance the current practices further (iii) many conventional and BIM based opportunities to extend the current Visual Management implementations exist for the sector.

Originality/value

The highways construction and maintenance sector in England has been systematically deploying lean construction techniques in its operations for a while. One of those lean techniques is a close-range visual communication strategy called Visual Management. The literature on the Visual Management implementation in construction is scarce and generally limited to the building construction context. This paper documents the current industry practice in conventional and Building Information Modelling (BIM) based Visual Management and identifies a set of recommendations and some Visual Management ideas for future implementation efforts in the highways construction and maintenance sector.
\end{abstract}

Keywords: Lean construction, Visual Management, Building Information Modeling, highways, roads, infrastructure construction

Paper type: Case study

\section{Introduction}

Partly due to the concrete lean construction vision of and contractual obligations imposed by the main governmental client, the deployment of lean construction has gained momentum in England's highways project supply chain since 2009 with the increasing implementation of some lean construction techniques, active lean construction engagement of some large contractors and significant efficiency targets (Chen et al., 2012; Drysdale, 2013; Fullalove, 2013). Lean construction is an umbrella term referencing to a combination of operational research and practices tailored to the architecture, engineering and construction (AEC) industry that take their roots from the lean production system developed at Japanese automobile manufacturers (Koskela, 1997; Green, 1999; Howell, 1999; Jørgensen and Emmitt, 2008). The broad gamut of lean implementation efforts includes Visual Management (VM) as an information management strategy based on the effectiveness of sensory communication to increase process transparency (Achanga et al., 2006; Bhasin and Burcher, 2006; Parry and Turner, 2006; Alves et al., 2012).

Presently, there is paucity of literature discussing the application of VM at roadwork interfaces in England. Current applications and perceptions are mostly limited to the use of visual performance boards (e.g. Ansell et al., 2007; Chen et al., 
2012; Drysdale, 2013; Highways Agency, 2010) with little information and empirical research on the current condition of the VM strategy. Also, apart from the information giving visual indicators (performance boards), many different types of more advanced visual tools, such as visual signals, visual controls and visual guarantees, which are particularly effective in limiting and guiding human behaviour and process outcomes through various sensory clues in different managerial efforts (Galsworth, 1997; Monden, 1998; Ortiz and Park, 2011), are also applicable in construction within the VM strategy (Emuze and Saurin, 2015). Beyond the use of different visual tools, VM as a managerial strategy, which essentially stems from the manufacturing industry, possesses its own implementation features and challenges in construction (Tezel et al., 2015). Moreover, Building Information Modeling (BIM) based systems have started to replace some conventional VM tools (Sacks et al., 2012). The efficacy of those different implementation approaches and the conditions of the current VM realisation within the highways construction and maintenance context in England still need to be determined. It is also necessary to identify VM implementation opportunities that are compatible with the current highways construction context to contribute to the emerging lean construction implementation and research in highways construction, and efficiency targets in the country.

Therefore, the aim of this paper is to investigate the current realisation of VM and to explore the possible opportunities for future VM implementations in highways construction and maintenance projects in England. The paper is organised as such; following a comprehensive literature review on the VM concept and its application in construction, the research methodology (case study and focus group) and research findings sections are presented. The findings from the employed research methodologies are also discussed to further clarify the as-is situation and to constitute a base for future VM implementation discussions within the highway construction context in England.

\section{Visual Management}

$\mathrm{VM}$ is one of the core practices of the lean production system (Bryde and Schulmeister, 2012). It is a managerial strategy that suggests sharing relevant and easy-to-understand sensory information close to its point of use (i) to increase the level of process transparency or the communication ability of process elements (Koskela, 2001), (ii) to stimulate discussion and coordination among the workforce (Bititci et al., 2015), (iii) to facilitate self-management and continuous improvement (Murata and Katayama, 2010), (iv) to impose consistency and discipline in process outcomes (Monden, 1998), (v) to set a systematic mechanism to share relevant and objective information from the organisational environment (Suzaki, 1993) and (vi) to support internal and external marketing efforts (Liff and Posey, 2004). The main characteristics of VM are (Greif, 1991); the information is presented in a self-service fashion to create information fields, (ii) the information is entirely determined ahead of time, and (iii) it relies little or none on verbal or textual communication. Ultimately, all those outcomes contribute to an increased process transparency and the realisation of the main lean production system goals of reduction of process waste, mitigation of overburdens on process elements and minimising the unevenness or fluctuations in processes (Ohno, 1988). Given the necessary training and opportunity in place, staff can develop their own visual systems by their own work process needs (Suzaki 1993; Hirano, 1995; Galsworth, 2011).

In practice, VM is implemented by using one or a combination of four types of visual tools (Galsworth, 1997); (i) the visual indicator that give only information (e.g. safety or traffic signs), (ii) the visual signal that signal and grab attention for an action 
(e.g. traffic lights), (iii) the visual control that limit and guide processes (e.g. motorway or parking lanes) and (iv) the visual guarantee (poka-yokes) that guarantee the desired outcome in processes by eliminating or warning of errors and mistakes through physical or electro-mechanical limitations (e.g. rumble strips or speed bumps on motorways). The human control of ignoring the given message is the highest with visual signals, whereas visual controls and visual guarantees leave little to no room for human control.

In lean production deployment efforts, the four types of visuals tools or their combinations as visual systems are used to create a visual workplace where VM is realised for different managerial efforts. The initial step to a visual workplace is often times implementing a systematic workplace structuring and housekeeping methodology called the 5S (Osada, 1991). The 5S is an acronym for the five steps in the methodology; systematic arrangement or sorting process items, setting process items in order to achieve a workplace standardisation, shining or systematic cleaning/maintenance checks, standardising the first 3S and finally, sustaining the methodology itself (Hirano, 1995).

Following the 5S, highly visual technical and procedural standards (e.g. specifications and work instructions) are located close to their point of use (Maskell and Kennedy, 2007). Announcements, desired behaviours, best practice examples, visual aids, process charts, end-product samples and A3 sheets summarising the continuous improvement process or important quality practices are integrated into the workplace (Shook, 2008). Organisation-wide, workstation and subcontractor/supplier related performance indicators are put on visual performance display boards with their target and actual values (Emuze and Saurin, 2015). Those figures should be easily understood and open to everyone at the workplace. Often times, staff hold regular meetings around those performance boards to focus their discussions on critical points (Suzaki, 1993). In some cases, condensed and essential visual information (e.g. key performance indicators, quality and safety issues, standards etc.) are consciously displayed together in the same area to managers or departments' staff to focus and trigger the discussions of regular meetings in what is called obeya rooms or "large rooms" (Aasland and Blankenburg, 2012).

After implementing visual workplace structuring, visual standards and visual performance boards, more advanced concepts such as visual controls and visual guarantees are introduced to the workplace. Visual controls can be used in material logistics control, process control, quality control, safety control, equipment control, project control and maintenance control efforts (Ohno, 1988; Hirano, 1995; Jang and Kim, 2007; Ortiz and Park, 2011). Relatively simple artefacts and methods such as coloured cards, colour coding, shadowing, the Gestalt law can be employed to realise those control efforts (Hirano, 1995). For instance, the renowned production kanban in the lean production system is essentially a visual control to harmonise pull-production, which is based on the exchange of specially designed cards (signalling artefact) among work units to control the amount of production and the level of work-in-progress/stocks (Rother and Shook, 1998). Critical processes, in which a higher level of standardisation in terms of process outcome quality, processing times or safety are required, are redesigned with physical and/or electro-mechanical impositions (Shingo, 1986). Depending on their design, they can warn the operator of a deviation or an unsafe situation or guarantee the outcome altogether without leaving any options to the operator's control (Fisher, 1999). Those VM systems are called visual guarantees or poka-yokes.

\section{Visual Management in construction}


The implementation of VM in construction has found place for itself in mostly the lean construction literature. The earlier discussions revolve around how to increase process transparency on construction sites (Koskela, 1992; Dos Santos et al., 1998; Formoso et al., 2002; Heineck et al, 2002). The gist of those discussions is to integrate more information into construction process elements, to remove barriers before construction information flows, to learn more about and adopt transparency increasing practices from the manufacturing industry into construction (e.g. the 5S) and to try novel VM tools and techniques for construction with the help of emerging technologies.

Following on those earlier discussions, a plethora of works demonstrating the application of various VM tools/ techniques originated from the manufacturing industry in construction can be seen. For instance, the kanban material control system has been widely discussed and implemented in the building construction context to date (Tommelein and Weissenberger, 1999; Arbulu et al., 2003; Yu et al., 2009). A successful application of the kanban system for material control and safety management purposes in metro construction projects was also reported (Jang and Kim, 2007). In building construction projects, a visual production-levelling concept called heijunka was successfully adopted in on-site concrete based mixtures production (Alves et al., 2009). The Last Planner System, which has offered an alternative to the Critical Path Method (CPM) for more than 20 years with its underlying collaborative approach, relies on the extensive use of visual boards and simple visual indicators (e.g. Post-It stickers and small magnets) in the planning process (Ballard and Howell, 1997; Koskenvesa and Koskela, 2012).

The Building Information Modelling (BIM) technology can extensively support lean construction and VM realisations (Sacks et al., 2010). Along with visual clash detections, BIM enabled 4D/5D visual simulations for optimum resource, time, safety, space, risk and constructability analysis have been used in lean efforts (Gerber $e t$ al., 2010). There are attempts to visualise the flow of information on construction sites using IT systems. One of the interesting efforts in BIM based workflow visualisation for building construction projects is the KanBIM prototype, in which process and product information are visualised through the pulls or signals of the user interfaces displaying the maturity of tasks planned and the status of work underway (Sacks et al., 2012). Although partly hampered by software interoperability and compatibility issues in application, the VisiLean prototype also offers some interesting workflow visualisation/simulation opportunities for highway construction planning and control efforts (Dave et al., 2013). Works to visually level the use of plant in construction projects through virtual kanbans, particularly in the use of excavators, graders, forklifts and trucks in earthmoving for highway construction (Kirbach et al., 2014) and building construction works (Barbosa et al., 2013), also exist.

Recently, the VM concept has been investigated as a managerial strategy. Tezel et al. (2015) discussed the implementation features of the VM strategy in building construction projects in Brazil. Tjell and Bosch-Sijtsema (2015) demonstrated that the deployment of the VM strategy in the construction design process along with BIM brought extensive benefits in coordination. Innovative project management planning and control solutions by using conventional VM tools (i.e. boards, cards etc.), in connection with the Last Planner System, have been devised (Brady, 2014; Viana et $a l ., 2014)$. Ko and Kuo (2015) demonstrated a successful implementation of VM with its peculiar manufacturing based tools (i.e kanban cards, andon boards) in formwork operations.

Innovative strategies in construction can be successful if both team members and management are highly interested in them, both during initiation and implementation 
stages (Ling, 2003). Another important aspect to the successful implementation of a strategy is the alignment of leadership across hierarchical levels (O'Reilly et al., 2010). Thus, obtaining both management and team commitment for VM across different hierarchical levels are important. While implementing a strategy, being clear with the strategy itself, avoiding an imposing top-down approach and effective communication across teams and functions should be paid attention to (Crittenden and Crittenden, 2008). Construction organisations are also sensitive to having the business case for the implementation of a strategy (Stewart et al., 2002). Also, the strategic directions of construction organisations and construction projects can be significantly affected by external stakeholders and their influences, such as the client's priorities or vision (Olander and Landin, 2005).

Giving little attention to the realisation features and conditions of the VM strategy itself, the VM discussions in construction has mostly been confined to building construction projects with an emphasis on implementing manufacturing based VM tools in construction. Context specific discussions illustrating what to do to disseminate and sustain VM efforts are mostly absent. It can be inferred from the literature that the empirical research on VM in transportation or infrastructure projects are also scarce. Additionally, a more general view to its realisation is necessary focusing on its challenges and benefits in this context. Therefore, this paper aims at understanding current VM implementation, as a managerial strategy, in the highways context with its barriers and future implementation opportunities. In doing so, the paper explores the current realisation of and opportunities for VM through its various visual tools applied in the field. Although there are some commonly used VM tools identified from the literature (i.e. the $5 \mathrm{~S}$ visual workplace structuring, kanbans etc), the information need in different work contexts may necessitate the development of novel VM tools fit for that specific context (Galsworth, 2011). Therefore, along with determining the current VM situation, this paper also aims at proposing some future VM implementation options for the highways context. Highways construction and maintenance projects are generally spread over large areas with many mobile construction teams/subcontractors working in different locations. Site offices and facilities are grouped in compounds that are generally detached from the actual construction field. Earthworks, underground utilities, drainage systems, electro/mechanical systems (i.e. variable sign boards, gantries etc.) and top surface layering are of the important construction and maintenance activities. Most of the time, the actual work is executed in parallel with the traffic flow in a live traffic situation, which renders traffic management an essential concern. Also, in the highways context in England, the main client is a governmental organisation that is able to affect the decisions large contractors take.

\section{Research methodology}

In order to understand the current VM implementation conditions and future VM implementation options for highways construction and maintenance projects in England, the case study and focus group research methodologies were used. The initial research strategy adopted was exploratory and relied on multiple case studies. Exploratory case studies are suitable when a phenomenon out of the researcher's control is investigated in its real life context (Yin, 2003). In management research, case studies have often been used to study events that are unusual, noteworthy, unfamiliar, or involve change. Furthermore, case studies are frequently employed to explain the implementation of new methods and techniques in organizations (McCutcheon and Meredith, 1993). The unit of analysis in this investigation is the VM implementation strategy and its practical means (visual tools) adopted by different highway 
construction and maintenance sites. The case studies provided with rich insights on the current VM realisation and future research/application opportunities.

Five major highway construction sites in England were visited over the course of four months (between April - August, 2015). All sites were identified and connected through the main governmental body that is responsible for managing the highways network in England. The sites are known to have some sort of lean awareness and efforts to advance their lean construction practices, which they drive through their lean improvement managers. The Tier 1 (main) contractors of the sites have given momentum to their lean construction efforts after 2012 with a firm drive and demand from their main client, the governmental body. Those lean efforts have also been tried to cascade through their Tier 2 (subcontractors) contractors. Some attributes of the visited sites can be seen in Table 1 .

\section{$<$ Please insert Table 1 around here $>$}

The data collection methods of the case studies included site observations on the field, in the site office and compound, photographic documentation, open-ended, semistructured interviews with process improvement managers, informal discussions with the construction managers and investigation of the site archives. The initial findings were triangulated by a semi-structured questionnaire distributed to some of the case projects' personnel. The realisation of the data collection methods by each case site can be seen in Table 2. The details of the case interviews with the business improvement managers can be seen in Table 3

\section{$<$ Please insert Table 2 around here $>$ \\ $<$ Please insert Table 3 around here $>$}

After completing the VM case studies, a workshop event focusing on conventional and IT based VM implementation in highways construction was organised to set the scene for the focus group research. Focus group research involves organised discussion with a selected group of individuals to gain information about their views and experiences of a topic (Krueger and Casey, 2008). Focus group discussions are particularly suited for rapidly obtaining several perspectives about the same topic, including gaining insights into different people's shared understandings of a phenomenon (Morgan, 1997; Stewart and Shamdasani, 2014).

The event was promoted through the construction management community and among process improvement practitioners in the highway construction and maintenance supply chain in England. Providing a rich platform for discussions, it brought together 40 attendees from the infrastructure construction sector and academia. The attendees were explained the purpose of the event beforehand with a detailed event programme. The event was divided into two sessions; where the first sessions revolved around conventional and BIM based VM presentations (eight in total) by industry experts, whereas the second sessions focused on a group exercise to identify the VM challenges in the existing practice and possible solutions. After the presentations, all the attendees were randomly assigned into seven groups and each group was asked to give their feedbacks for possible VM implementation project (s) on specific A3 sheets. The A3 sheets consist of four sections; as-is process, problem analysis, proposed VM solution and VM implementation plan(s). Each group then presented and discussed their proposed VM project with the attendees, which stimulated open-ended group 
discussions. The discussions were moderated by the authors and recorded with the permission of the attendees. Table 4 displays the profile of the focus group discussion attendees.

\section{$<$ Please insert Table 4 around here $>$}

After preparing the metadata log, the transcription of the semi-structured case interview notes were analysed in connection with the findings from the systematic observations of the VM practices and site conditions, site photos, questionnaires and notes from the informal discussions to draw an overall picture of the VM situation. The interview questions' focus was of the interpretative and leading type (see Table 3 ). The triangulation of the statements given by the interviewees was sought where possible. The data were essentially analysed grouping the findings as per the main interview focuses. No systematic coding structure was used. The same strategy applies to the analysis of the focus groups. As the authors managed to record the focus group discussions on a voice recorder and the group suggestions on A3 papers, after the systematic transcription of the recordings, the data were compiled in parallel with the discussion and $\mathrm{A} 3$ sheet findings. The main analyses of the focus groups were over the groups' perception of VM, its main barriers and what to do to overcome those barriers, and its future implementation options.

\section{Case study findings}

Before the detailed discussion of the cases, a summary of the main findings from the case studies can be seen below.

- The mostly commonly used VM tool is visual performance boards.

- The process improvement managers, who are generally responsible for implementing lean construction techniques in the projects, have not implemented some more advanced VM tools due to various reasons explained in the cases analyses.

- The process improvement managers may sometimes struggle with obtaining the full support of their senior management, relating to their operational personnel's needs and managing their own workload for further VM improvements.

- The companies' main governmental client's priorities and drives affect the companies' decisions on the implementation of VM and other lean construction techniques

- The deployment of VM on the construction sites is limited.

- There are many improvisational VM practices used by the site personnel. Those practices can be studied to further understand their information needs.

- Most of the visual information shared with the site personnel is related to health and safety.

- The site personnel request to see schedule/programme related, quality related, and process related information more.

- The housekeeping standardisation is low on the sites. The $5 \mathrm{~S}$ methodology can be tried.

- There is a lack of clarity among the process improvement managers as to how to quantify the benefits of VM

- Many additional VM implementation ideas at the operational level (on-site) for highway construction and maintenance were identified from the cases. See the 
section titled "Visual management implementation ideas by process improvement managers"

- The BIM use is limited particularly among the site personnel

\section{Visual Management in construction site offices and compounds}

Case 1's process improvement manager had built on his personal initiative an obeya room to hold their regular meetings at the managerial level (see Figure 1 for the obeya room). The manager stated that after a benchmarking study, their main governmental client's visual performance boards had inspired him for the obeya room. He also noted that the company would use obeya rooms for their future projects as they found the obeya approach effective in focusing their meetings with around 40 percent savings in meeting durations. The manager had heard of more advanced VM tools but did not know of the details of their implementation. There were different visual boards in the office mainly for the Collaborative Planning System (the UK's equivalent to the Last Planner System in the US) and health and safety related information. The compound area was clean and orderly; yet their Tier 2 subcontractors had diverse housekeeping levels in general. There was no systematic $5 \mathrm{~S}$ effort in the office or compound. The housekeeping refers to the order, identification (i.e. name, location, quantity etc.) and general cleanliness of a work setting and its items (i.e. material, tools, equipment, machinery, walking paths etc.). Thus, the subcontractors were differing in their housekeeping efforts in the areas allocated to them and in their containers/maintenance vans. The compound area generally contains site offices, parking areas, testing laboratories, equipment/machinery maintenance workshops, and main material warehouses and lay-down areas in the highways context. In terms of IT systems, management had installed in the office and around the compound static touch pad units to record/collect data on near misses. The recorded near misses and their corresponding countermeasures by the management were being displayed on specific safety boards. It was identified that the BIM technology had not been employed.

\section{$<$ Please insert Figure 1 around here $>$}

Case 2's process improvement manager stated that she knew there was more to lean construction than Collaborative Planning (referring to VM) and she became frustrated when people associated only visual boards with VM. The manager was aware of different VM opportunities; yet when discussed further, it was found that she had little to no knowledge of or training on how to implement more advanced VM approaches, such as visual controls or visual guarantees. The manager had tried to implement the $5 \mathrm{~S}$ in their warehouse located in the project compound but could not have obtained a real result due to lack of ownership. The $5 \mathrm{~S}$ programme was on hold at the time of the visit. There were collaborative meeting boards for different departments (i.e. traffic management, design, health and safety), around which the members of those departments could discuss their short-term plans, problematic situations, work constraints and continuous improvement/problem mitigation efforts (see Figure 2 for an example of the visual team performance boards). Daily meetings with the site staff were held around a large aerial photography of the project on which the staff members could interact. The abundance of visual performance boards for different performance indicators leaped to the eye. The project's Collaborative Planning efforts were executed on large boards with Post-It stickers. Daily programme with some critical traffic management issues was communicated to the site staff on a colour-coded A3 daily coordination sheets. The compound area was clean and orderly; yet their Tier 2 
subcontractors had diverse housekeeping levels in general. The site management had distributed 74 tablet (mobile) computers to their staff so that they could instantly record or see any safety, quality or programme related issue on the field.

\section{$<$ Please insert Figure 2 around here $>$}

Case 3 site office had an obeya type designated meeting area filled with many visual performance indicators and visual information for the managers. There were different visual boards in the office mainly for the Collaborative Planning System and key performance indicators. A daily coordination document called Start of Shift that summarises what needs to be done and critical issues for safety, quality and traffic management with some renders from the project's BIM model was distributed to the site staff at the beginning of each shift (see Figure 3 for the preparation of the BIM based Start of Shift document). The process improvement manager's main discussion on VM revolved around their visual performance boards and the Start of Shift document. He said he had heard of some other VM tools but did not know much about their implementation details. The compound area was clean and orderly; yet their Tier 2 subcontractors had diverse housekeeping levels in general. There was no systematic $5 \mathrm{~S}$ effort in the office or compound. The construction progress could also be tracked and seen by anyone through a web-based system integrated with Google Earth. A 3D plant simulator was used to visually train the plant operators. 3D BIM models were used mainly for design purposes and as a facilitator tool for the Collaborative Planning meetings.

\section{$<$ Please insert Figure 3 around here $>$}

Similar to Case 2, some departments in Case 4 had been using specific collaborative meeting boards. Visual performance boards were also rife in the site office and compound. The Collaborative Planning meetings had been run on large visual boards with colour-coded Post-It stickers. The connection between their Collaborative Planning efforts with the site staff was maintained through daily meetings called the 4C (the acronym for Collaboration, Coordination, Communication and Cooperation). The compound area was clean and orderly; yet their Tier 2 subcontractors had diverse housekeeping levels in general. There was no systematic $5 \mathrm{~S}$ effort in the office or compound. A relatively more extensive use of the BIM technology was identified in Case 4. The site management had purchased a large touch screen to display their BIM model for design briefings, safety simulations, as a facilitator for Collaborative Planning and the 4C meetings, customer engagement and 4D (time/schedule integrated) BIM sequence simulation studies (see Figure 4 for the use of BIM in Collaborative Planning meetings). A mobile and cloud computing based application purchased from a prominent software vendor for their BIM integration had been tried for a while.

\section{$<$ Please insert Figure 4 around here $>$}

Case 5's process improvement manager was trying to initiate a $5 \mathrm{~S}$ programme on the site. He was struggling with getting the consent of the site project manager, who was sceptical of the potential benefits. The study of the compound area, which is smaller compared to the other visited compounds, revealed many improvement opportunities in terms of housekeeping. The manager was open to collaboration with academia to take their VM initiatives further. Collaborative Planning meeting and various visual 
performance boards were identified in use in the site office (Figure 5 for an example of Collaborative Planning meeting board with Post-Its). The Collaborative Planning system had still been introduced to the site by two external consultants at the time of the visit. The project BIM model was incomplete and its use was mostly limited to the constructability studies and design reviews of the wastewater drainage system.

\section{$<$ Please insert Figure 5 around here $>$}

\section{Visual Management on construction field}

It was found that the deployment of transparency increasing visual tools and the VM strategy is limited at the operational level (on actual construction fields). Most of the visual information shared with the workforce is related to health and safety. Case 1's process improvement manager highlighted this overemphasis given to health and safety related information and underlined that the same information sharing mind-set should be extended to communicating quality and programme (schedule) related information to their workforce. One of the senior construction managers at Case 3 stated during the field visit that their construction workers tend to make some fundamental quality related mistakes in their daily operations (i.e. extensively touching the concrete vibrator to concrete reinforcement bars while pouring in-situ concrete). Using an A3 quality sheet for concrete pouring operations was suggested to the manager. With the absence of readily available information, the workforce on the field tends to use improvisational practices to integrate information into their workspaces. They simply mark the orientation of a manhole by spraying paint onto the ground or erecting colour-coded wooden sticks to mark the location of underground services (i.e. water and gas) or the tops and toes of excavation slopes (see Figure 6 for an improvisational visualisation effort used to locate the underground gas utility). The site teams had implicitly developed improvisational visual communication systems.

\section{$<$ Please insert Figure 6 around here $>$}

Coupled with a lack of awareness of the range of different VM implementation possibilities, it was observed that the managers interviewed find it hard to relate to the site conditions and actual operational information needs for VM to the desired extent. Case 5's process improvement manager stated: "Suggestions (for VM) would need to come from the construction teams. For anything to be owned and used, ideas need to come from those who will use it. Our lean initiative is not mature enough to collect those ideas and turn them into VM solutions." From the managers' perspective, Case 2, Case 3 and Case 5's process improvement managers openly complained about the lack of workforce or a consistent team to drive their initiatives including VM. Case 1, Case 4 and Case 5's manager underlined that the industry culture that assumes lean principles/techniques are not applicable in construction should be challenged. Case 5's process improvement manager denoted that the abundance of different construction related programmes running simultaneously (i.e. Considerate Constructors, Sustainable Construction, Lean Construction etc.) put pressure on their construction site managers and they found it hard to pay sufficient attention to and to take enough time for each of those initiatives. No systematic approach that develops/investigates new VM solutions for the operational on-site staff in the studied construction sites was identified.

All of the visited sites had been supported to varying degrees by lean construction consultants. However, it was identified that the scope of this support was still largely 
limited to the implementation of the Collaborative Planning System, which is the UK's identical of the Last Planner System (Ballard and Howell, 1997). The companies' main client's (a governmental agency responsible for the highways network in the UK) priorities and drives affect the companies' decisions on the support from consultants for lean construction. The consultant support can be broadened to cover VM and the $5 \mathrm{~S}$ efforts as well to experiment with different VM implementations on those sites.

Another common point identified from the interviewed process improvement managers and other construction managers through informal discussions is the lack of clarity in quantifying the benefits of VM. The managers repeatedly stated that they had "sensed" the benefits of VM but struggled to put those benefits into numerical figures. Measuring and demonstrating the benefits in objective terms are important so as to justify the return of investment and advance any VM effort. Case 2's manager's statement is summarising the issue; "you (process improvement practitioners) have to show to the senior management the VM benefits first before asking for further investments". The managers were explained different techniques and approaches to quantify the VM benefits such as time study analysis (comparing before the VM - after the VM cases in terms of process times), the cost (material, time, man-hours) of not doing things right the first time and the dropping number of Non-Conformances (NCRs), operational questions or Request for Information (RFIs).

All of the visited construction sites are managed by Tier 1 (main) contractors that subcontract some of their critical works (e.g. excavation, reinforced concrete structure construction, soil stripping etc.) to Tier 2 subcontractors. Although a certain level of standardisation has been achieved particularly in health and safety related regulations and rules, different sub-contractors tend to have different practices (i.e. different housekeeping efforts). In order to increase the level of standardisation in their lean construction and VM practices, as the process improvement managers at Case 2 and Case 3 underlined, the roles and responsibilities should be clearly defined among the subcontractors. The clarification of contractual engagements is important for future efforts. Table 5 shows the identified VM practices on the construction fields. There are some commonalities in practices between the construction sites, most notable of which are the existence of improvisational practices, limited housekeeping and the abundance of health and safety related efforts (see Figure 7 for a mobile health and safety board located on-site ).

\section{$<$ Please insert Figure 7 around here $>$ \\ $<$ Please insert Table 5 around here $>$}

\section{Visual Management Questionnaire}

In order to triangulate some of the findings, an online semi-structured questionnaire for improved anonymity was distributed to the personnel in Case 2 and Case 3. The findings of the questionnaire can be seen in Table 6 .

\section{$<$ Please insert Table 6 around here>}

According to the questionnaire findings, (i) visual boards are frequently-occasionally used by the personnel, (ii) the level of site orders are generally found average, which indicates some improvement opportunities, (iii) the current level of shared visual information on construction field is on the average-below average scale, (iv) the most frequently requested information are schedule/programme related, quality related, 
process related information; health and safety related information have rarely been mentioned, which supports Case 1 manager's statement, and (v) the BIM systems for visualisation in the case projects have been rarely used, especially by more operational staff (engineers, foremen, traffic management and health and safety officers).

\section{Visual Management implementation ideas from process managers}

The interviewed process managers were asked to provide new VM implementation ideas at the operational level (on-site) for highway construction and maintenance projects. It should be acknowledged that different project sites run by different companies can have different conditions and priorities. Nevertheless, the implementation ideas captured will still provide some insights on future VM implementations.

Case 1's process improvement manager stated that they didn't not use any specific VM system at the operational level and suggested to implement the following VM ideas:

1. Task-based on-site mobile boards displaying critical quality related steps, best practices and programme expectations that show where a task is and where it should be according to the construction programme. He also mentioned that he would like to communicate the cost of errors/mistakes in a simple manner to their workforce;

2. On-site visual method statements (for safety and quality);

3. Specially designed on-the-job training areas powered by visual tools;

4. BIM based interactive on-site boards.

The process improvement manager at Case 2 gave the following VM implementation ideas:

1. Taking daily briefings to the site level by having all the collaborative planning and performance boards in the back of a van (mobile).

2. "Method statements could be visualised."

3. "Schedule and project cost related information should be taken to the site level. Construction staff generally doesn't know how they are doing and cannot understand the bigger picture."

4. Root cause analysis in continuous improvement efforts should be visualised.

The process improvement manager at Case 3 provided with the following VM implementation ideas:

1. Standardised visual performance boards that can be used in different projects in the future.

2. "The continuous improvement process should be visualised."

3. A standard visual system that binds daily planning (programme) from the collaborative planning efforts with the site staff.

The process improvement manager at Case 4 provided with the following VM implementation ideas:

1. "Visual solutions that will demonstrate to the workforce on the field how and what they do on a day to day basis fits into the bigger picture for the project on which they work (i.e. are we ahead of programme or behind programme / will the job make a profit? etc.). Our project cannot provide this information in a consistent or easy to understand format for the time being." 
2. "If our main customers had a consistent, workforce friendly update format for all projects to produce from the information that projects already have to produce regularly (i.e. Monthly cost reports.) so that it would take little extra resource to produce." The format of those routine reports should be simplified and easy to understand/generate.

The process improvement manager at Case 5 gave the following VM implementation idea:

1. A 5S systematic housekeeping implementation to increase the level of on-site visual workplace standardisation and order. The manager recommended to start the $5 \mathrm{~S}$ implementation process within a pilot area.

2. "Managers should collect VM ideas from the personnel working on the field."

\section{Focus Group Findings}

Following the case studies, a VM event was organised for professionals from the highways sector, lean construction consultants and academia to raise awareness of the VM subject and to create a platform for the discussion of the topic (see Figure 8 for the focus group participants working on the VM subject). The findings from the group studies can be seen in Table 7 .

$<$ Please insert Figure 8 around here>

$<$ Please insert Table 7 around here $>$

A summary of the findings from the group study presentations and discussions can be seen below.

- "The duplication of data, generated information, produced technical drawings etc. within different stakeholders and between different organisations in the sector is a form of waste." It should be tackled before information visualisation. A benchmarking event with industry leaders can be organised to identify the areas of collaboration and way-forward. For instance, a similar benchmarking structure was organised in the health care sector.

- The contractual structure in the highways sector sometimes forces companies to move into different areas with new contracts in which a company have to work with teams with minimal knowledge of lean and VM. Therefore, they have to start from the beginning hampering the further development in their lean and VM efforts.

- Getting higher lean construction implementation scores from the main governmental client helps the companies (Tier 1 and Tier 2) win future contracts. It is an important driver for the companies.

- VM will improve employee morale, work efficiency, collaboration between the main client and supply chain partners and help construction move to the production mind-set.

- Implementing different VM solutions in pilot areas and showing the benefits will be useful. It may take some time (more than a year) so patience is necessary.

- As indicated by a participant, "people generally don't destroy what they create." Thus, allow people to create and experiment with their own VM solutions. Involve them into the implementation process more. 
- VM should extend more into actual production areas in the form of different practices such as the $5 \mathrm{~S}$, pull production control (i.e. kanbans), mistake proofing (poka-yokes) etc.

- Showing the ultimate project goals and company vision is important in your VM efforts. "Show people also the destination along with the journey". It will be also useful to visualise the connections between different work groups and processes.

- Cultural issues, which are about getting people to embrace the VM strategy should be better addressed. It is a challenge to get the actual benefits across senior management. Quantifying those VM benefits can be useful.

- As indicated by a group, 'how you 'sell' or 'market' the use of the collated information to your workforce and your senior management is as important as the content and presentation of the information."

- Different VM practices should be audited within the industry and the best practices should be communicated to all workforce and management.

- It would be useful to have a visual system on which people can visually record the waste in their work processes (self-auditing).

\section{Discussion of the findings}

The main finding from the case studies and focus groups is that the current VM implementation scope in highway construction and maintenance projects in England can be broadened beyond visual performance boards and extended more into the production area (construction field). Stronger collaboration ties with academia will help raise awareness on the range of VM implementation options in conventional and BIM based VM solutions for the companies in the future. Additionally, action and design science research efforts can be undertaken within industry-academia collaborations for pilot VM implementation projects. Successful implementation cases will give impetus to the lean construction and VM efforts in the sector. Inter-company lean construction training curricula can also be redesigned with the support of academia for more emphasis on the diverse lean and VM practices.

For information sharing and benchmarking purposes, a collaboration platform among prominent construction groups in the sector can be formed under the leadership of the main governmental client. A similar collaborative platform has been found effective in disseminating the VM effort among building construction companies in Brazil (see Tezel et al., 2015). For the companies, the main governmental client's lean construction vision and impulsion are of great importance for their decisions and priorities (e.g. level of investment, willingness to collaborate with each other and academia etc.). Therefore, the client's lead will be a determining factor in disseminating and advancing the current practices, which is generally the case for innovative process improvement approaches in construction (Briscoe et al., 2004). Auditing the current best-practices and innovative VM solutions in the highways construction sector to establish a VM implementation database may also contribute to the dissemination and standardisation of effective VM practices through the supply chain. As stated by Case 
2's and Case 3's process improvement managers, contractually defining the roles and responsibilities of Tier 2 subcontractors for the VM strategy may also raise the level of standardisation in practice. Also, letting the workforce experiment with or devise their own VM solutions can help disseminate and sustain the strategy as stated by a focus group.

The captured VM ideas are worth investigating further and likely to be relevant as they reflect an observed, actual implementation need coming from sector professionals. There are two important points to ponder over while implementing the identified ideas; obtaining the ownership of senior management, which was found to be problematic from time to time, and involving workforce in the implementation (i.e. design and use of a VM system) process. Demonstrating the expected qualitative and quantitative benefits of a VM implementation project/idea can contribute to overcoming both obstacles. Currently, there is a lack of clarity among the business improvement managers for methods to be used in quantifying the benefits of the VM strategy. This suggestion of having the business case links to the statement identified from one of the focus groups that VM should be better "sold" to the managers and workforce. For original and relevant VM solutions, the companies should refer more to the ideas of their operational workforce.

The level of utilisation of BIM for VM was varying among the visited sites. The use of the BIM models was found low among the operational personnel in the case projects. The potential in using the BIM capabilities with lean construction and VM efforts should be better explained to the site managers. Given the fact that highway construction and maintenance projects often extend over large areas, mobile and cloud computing based BIM solutions will come to the fore. To take BIM models to the construction field, as in the KanBIM model (Sacks, 2012), the use of large and durable touch screens can also be tried to communicate nD BIM models to site staff. Highways construction information flow visualisation efforts likening to the VisiLean project can be furthered for the sector. In connection with BIM, the maturing concepts of the Internet of Things (IoT), advanced photogrammetry and rapid laser scanning (e.g. LiDAR and LADAR) will find place in lean construction and VM deployments in the highways construction and maintenance sector. The combined use of Geographic Information System (GIS) and BIM could lead to applications enabling visual control and monitoring of the supply chain of projects spread over large areas such as highways construction and maintenance (Irizarry, 2013).

\section{Conclusion}

VM as a visual communication strategy constitutes a fundamental part of lean production and construction deployments. It was found that the VM strategy has taken some momentum recently in the highways construction and maintenance supply chain in England in accordance with the main governmental client's lean construction vision. This resulted in large contractors' taking VM in their lean implementation agendas and accordingly, an increase in the number of publications discussing those implementations. However, the VM implementation efforts are still limited (mostly 
revolving around visual performance boards) with room for improvements in practice, particularly on the construction field. The highways construction and maintenance sector in England should investigate the current VM situation and future implementation ideas discussed in this paper to take their ambitious lean construction goals further.

Although the current VM implementations are limited in the highways supply chain, the interviewed process improvement managers and participants in the focus group were generally approving of the benefits of VM discussed in the literature. Due to the widespread use of visual performance boards, the contributions of VM to the team/site coordination were highlighted by the business improvement managers. However, apart from some evidence from Case 2 and Case 3, the overall satisfaction of both managers and workforce with VM is not clearly known yet. Also, whether VM is mainly pursued by the companies due to the firm impetus by the main governmental client to win future contracts or actually, due to its benefits, should be better understood. The latter motivation will expectedly lay a stronger foundation for more advanced VM implementations. A broader research effort is necessary to identify these points.

The significant barriers before the VM strategy in the highways supply chain discussed in the paper should be carefully addressed to disseminate the VM strategy further. Alongside raising awareness, the business case for VM should be developed by quantifying its benefits for further VM implementations. This will help business improvement managers convince their senior managers for VM for a better strategic alignment of the efforts. However, one should be careful with not limiting the VM benefits to quantitative or monetary figures only; its qualitative benefits should also be recognised. Some of the problems the current VM implementations facing are related to the structure of the industry; the fragmentation and respectively, duplication of data/information and the project based nature of the business that hampers long-term improvement efforts.

It should be noted that both VM and lean construction are operational research fields with a greater emphasis on practice. Thus, for future research, the VM implementation ideas that are coming from the highways sector and highlighted in this paper can be put on trial through action and design research efforts. The VM ideas are proposed for testing in the field. This is to say the authors do not present them asserting that they will certainly yield benefits. Whether they will contribute to highways construction and maintenance operations are yet to be seen in future research and implementations. Also, the current VM implementations should be extended more towards the construction field and go beyond visual performance boards with the investigation of the implementation of other VM concepts like the 5S, kanban visual controls and poka-yoke mistake proofing systems in the supply chain.

The sector's prominent construction groups' and the main governmental client's leadership will expectedly continue to guide the future efforts. The level of awareness on how the BIM capabilities can support lean construction and VM should be increased. 
BIM integrated innovative VM solutions stemming from other maturing technologies (e.g. IoT, sensors, AutoID, laser scanning, advanced photogrammetry, mobile and wearable computing, Augmented and Spatial Reality, GIS, using drones and quadcopters etc.) can support or replace conventional practices and should be further investigated for VM and lean construction in the highways construction and maintenance supply chain in England.

\section{References}

Aasland, K. and Blankenburg, D. (2012), "An analysis of the uses and properties of the Obeya", In Proceedings of the 18th International Engineering, Technology and Innovation (ICE) Conference, pp. 1-10.

Achanga, P., Shehab, E., Roy, R. and Nelder, G. (2006), "Critical success factors for lean implementation within SMEs", Journal of Manufacturing Technology Management, Vol. 17 No. 4, pp. 460 - 471.

Alves, C. L. T., Milberg, C. and Walsh, K. D. (2012), "Exploring lean construction practice, research, and education", Engineering, Construction and Architectural Management, Vol. 19 No. 5, pp. 512-525.

Alves, C. L. T., Neto, J. P. B., Heineck, L. F. M., Kemmer, S. L and Pereira, P. E. (2009), "Incentives and innovations to sustain lean construction implementation", In Proceedings of the 17th Annual Conference of the International Group for Lean Construction (IGLC), Taipei, Taiwan.

Ansell, M., Holmes, M., Evans, R., Pasquire, C., and Price, A. (2007), "Lean Construction Trial on a Highways Maintenance Project", In Proceedings of the 15th Annual Conference of the International Group for Lean Construction $(I G L C)$, Michigan, USA.

Arbulu, R., Ballard, G. and Harper, N. (2003), "Kanban in construction", In Proceedings of the 11th Annual Conference of the International Group for Lean Construction (IGLC), Virginia, USA.

Ballard, G. and Howell, G. (1997), "Shielding production: an essential step in production control", ASCE Journal of Construction Engineering and Management, Vol. 124 No. 1, pp. 11-17.

Bhasin, S. and Burcher, P. (2006), "Lean viewed as a philosophy", Journal of Manufacturing Technology Management, Vol. 17 No. 1, pp. 56 - 72.

Barbosa, G., Andrade, F., Biotto, C. and Mota, B. (2013), "Heijunka system to level telescopic forklift activities using tablets in construction site", In Proceedings of the 21th Annual Conference of the International Group for Lean Construction (IGLC), Fortaleza, Brazil.

Bititci, U., Cocca, P. and Ates, A. (2015), "Impact of visual performance management systems on the performance management practices of organisations", International Journal of Production Research, (ahead-of-print).

Brady, D. A. (2014), "Using Visual Management to improve transparency in planning and control in construction", $\mathrm{PhD}$ thesis, University of Salford, Salford, UK.

Briscoe, G. H., Dainty, A. R., Millett, S. J. and Neale, R. H. (2004), "Client-led strategies for construction supply chain improvement", Construction Management and Economics, Vol. 22 No. 2, pp. 193-201. 
Bryde, D. J. and Schulmeister, R. (2012), “Applying lean principles to a building refurbishment project: experiences of key stakeholders", Construction Management and Economics, Vol. 30 No. 9, pp. 777-94.

Chen, C., Housley, S., Sprague, P. and Goodlad, P. (2012), "Introducing lean into the UK Highways Agency's supply chain", In Proceedings of the ICE-Civil Engineering, Vol. 165 No. 5, pp. 34-39.

Crittenden, V. L. and Crittenden, W. F. (2008), "Building a capable organization: The eight levers of strategy implementation”, Business Horizons, Vol. 51 No. 4, pp. 301-309.

Dave, B., Boddy, S. and Koskela, L. (2013), "Challenges and opportunities in implementing lean and BIM on an infrastructure project", In Proceedings of the 21th Annual Conference of the International Group for Lean Construction (IGLC), Fortaleza, Brazil.

Dos Santos, A., Powell, J., Sharp, J. and Formoso, C.T. (1998), "Principle of transparency applied in construction", In Proceedings of the 6th Annual Conference of the International Group for Lean Construction (IGLC), Guaruja, Brazil.

Drysdale, D. (2013), "Introducing lean improvement into the UK Highways Agency supply chain", In Proceedings of the 21 th Annual Conference of the International Group for Lean Construction (IGLC), Fortaleza, Brazil.

Emuze, F. A., and Saurin, T. A. (Eds.). (2015), Value and Waste in Lean Construction, Routledge, Oxon, UK.

Fisher, M. (1999), "Process improvement by poka-yoke", Work Study, Vol. 48 No. 7 , pp. 264-266.

Formoso, C. T., Dos Santos, A. and Powell, J. (2002), "An exploratory study on the applicability of process transparency in construction sites", Journal of Construction Research, Vol. 3 No. 1, pp. 35-54.

Fullalove, L.H. (2013), "Examples of lean techniques and methodology applied to UK road schemes", In Proceedings of the 21th Annual Conference of the International Group for Lean Construction (IGLC), Fortaleza, Brazil.

Galsworth, G. D. (1997), Visual Systems: Harnessing the Power of Visual Workplace, AMACOM, New York, USA.

Galsworth, G. D. (2011), Work that Makes Sense: Operator-Led Visuality, VisualLean Enterprise Press, Portland, USA.

Gerber, D. J., Gerber, B. B. and Kunz, A. (2010), "Building information modelling and lean construction: technology, methodology and advances from practice", In Proceedings of the 18th Annual Conference of the International Group for Lean Construction (IGLC), Haifa, Israel.

Green, S. D. (1999), “The missing arguments of lean construction", Construction Management and Economics, Vol. 17 No. 2, pp. 133-137.

Greif, M. (1991), The Visual Factory: Building Participation through Shared Information, Productivity Press, Portland, USA.

Heineck, L. F. M., Pereira, P. E., Leite, M. O., Neto, J. P. B. and Pinho, I. B. (2002), "Transparency in building construction: a case study", In Proceedings of the 10th Annual Conference of the International Group for Lean Construction (IGLC), Gramado, Brazil.

Highways Agency (2010), An Introduction to Lean Visual Management, Technical Report, Lean Improvement Division.

Hirano, H. (1995), 5 Pillars of the Visual Workplace: The Sourcebook for $5 S$ Implementation, Productivity Press, Portland, USA. 
Howell, G. (1999), "What is lean construction?", In Proceedings of the 7th Annual Conference of the International Group for Lean Construction (IGLC), Berkeley, USA.

Irizarry, J., Karan, E. P. and Jalaei, F. (2013), "Integrating BIM and GIS to improve the visual monitoring of construction supply chain management", Automation in Construction, Vol. 31, pp. 241-254.

Jang, J. W. and Kim, Y. W. (2007), "Using the kanban for construction production and safety control", In Proceedings of the 15th Annual Conference of the International Group for Lean Construction (IGLC), Michigan, USA.

Jørgensen, B. and Emmitt, S. (2008), "Lost in transition: the transfer of lean manufacturing to construction", Engineering, Construction and Architectural Management, Vol. 15 No. 4, pp. 383-398.

Kirchbach, K., Koskela, L. and Gehbauer, F. (2014), "Digital kanban for earthwork site management", In Proceedings of the 22nd Annual Conference of the International Group for Lean Construction (IGLC), Oslo, Norway.

Ko, C. H., and Kuo, J. D. (2015), "Making formwork construction lean", Journal of Civil Engineering and Management, Vol. 21 No. 4, pp. 444-458

Koskela, L. (1992), Application of the New Production Philosophy to Construction, Technical Report, Stanford University, USA.

Koskela, L. (1997), "Lean production in construction", In Alarcon, L. (eds) Lean Construction, AA Balkema, Rotterdam, The Netherlands, pp. 1-9.

Koskela, L. (2001), "On new footnotes to Shingo", In Proceedings of the 9th Annual Conference of the International Group for Lean Construction (IGLC), Singapore, Singapore.

Koskenvesa, A. and Koskela L. (2012), "Ten years of last planner in Finland-where are we", In Proceedings of the 20th Annual Conference of the International Group for Lean Construction (IGLC), San Diego, USA.

Krueger, R. A. and Casey, M. A. (2008), Focus Groups: A Practical Guide for Applied Research, 4th Edn. Sage, London, UK.

Liff, S. and Posey, P. A. (2004), Seeing is Believing: How the New Art of Visual Management can Boost Performance throughout your Organization, AMACOM, New York, USA.

Ling, F. Y. Y. (2003), "Managing the implementation of construction innovations", Construction Management and Economics, Vol. 21 No. 6, pp. 635-649.

Maskell, B. H. and Kennedy, F. A. (2007), 'Why do we need lean accounting and how does it work?", Journal of Corporate Accounting \& Finance, Vol. 18 No. 3, pp. 59-73.

McCutcheon, D. M. and Meredith, J. R. (1993), "Conducting case study research in operations management", Journal of Operations Management, Vol. 11 No. 3, pp. 239-256.

Monden, Y. (1998), Toyota Production System: An Integrated Approach to Just-inTime, 3rd Edn. Engineering and Management Press, Norcross, USA.

Morgan D.L. (1997), Focus Groups as Qualitative Research, Sage, London, UK.

Murata, K. and Katayama, B. (2010), "Development of kaizen case-base for effective technology transfer-a case of visual management technology", International Journal of Production Research, Vol. 48 No. 16, pp. 4901-4917.

Olander, S. and Landin, A. (2005), "Evaluation of stakeholder influence in the implementation of construction projects", International Journal of Project Management, Vol. 23 No. 4, pp. 321-328. 
O'Reilly, C. A., Caldwell, D. F., Chatman, J. A., Lapiz, M. and Self, W. (2010), "How leadership matters: The effects of leaders' alignment on strategy implementation", The Leadership Quarterly, Vol. 21 No. 1, pp. 104-113.

Ortiz, C.A. and Park, M.R. (2011), Visual Controls: Applying Visual Management to the Factory, Productivity Press, New York, USA.

Osada, T. (1991), The 5S's: Five Keys to a Total Quality Environment, Asian Productivity Press, Tokyo, Japan.

Parry, G.C. and Turner, C.E. (2006), "Application of lean visual process management tools", Production Planning \& Control, Vol. 17 No. 1, pp. 77-86.

Rother, M. and Shook, J. (1998), Learning to See: Value Stream Mapping to Create Value and Eliminate Muda, The Lean Enterprise Institute, Brookline, USA.

Sacks, R., Barak, R., Belaciano, B., Gurevich, U. and Pikas, E. (2012), "KanBIM workflow management system: prototype implementation and field-testing," Lean Construction Journal, 19-35.

Sacks, R., Koskela, L., Dave, B. and Owen, R. L. (2010), "The interaction of lean and BIM: a conceptual analysis", Journal of Construction Engineering and Management, Vol. 136 No. 9, pp. 968-980.

Shingo, S. (1986), Zero Quality Control: Source Inspection and the Poka-Yoke System, Productivity Press, New York, USA.

Shook, J. (2008), Managing to Learn: Using the A3 Management Process to Solve Problems, Gain Agreement, Mentor and Lead, Lean Enterprise Institute, Cambridge, USA.

Stewart D.W. and Shamdasani P.N. (2014), Focus Groups: Theory and Practice, 3rd Edn. Sage, London, UK.

Stewart, R. A., Mohamed, S. and Daet, R. (2002), "Strategic implementation of IT/IS projects in construction: a case study", Automation in Construction, Vol. 11 No. 6, pp. 681-694.

Tezel, A., Koskela, L.,Tzortzopoulos, P.,Formoso, C. and Alves, T.(2015), "Visual management in Brazilian construction companies: taxonomy and guidelines for implementation", Journal of Management in Engineering, Vol 31 No. 6.

Tjell, J. and Bosch-Sijtsema, P. M. (2015), "Visual management in mid-sized construction design projects", Procedia Economics and Finance, Vol. 21, pp. 193-200.

Tommelein, I.D. and Weissenberger, M. (1999), "More just-in-time: location of buffers in structural steel supply and construction processes", In Proceedings of the 7th Annual Conference of the International Group for Lean Construction $(I G L C)$, Berkeley, USA.

Viana, D., Formoso, C.T., Wesz, J. and Tzortzopoulos, P. (2014), "The role of visual management in collaborative integrated planning and control for engineer-toorder building systems", In Proceedings of the 22nd Annual Conference of the International Group for Lean Construction (IGLC), Oslo, Norway.

Yin, R. K. (2003), Case Study Research: Design and Methods, $3^{\text {rd }}$ Edn. Sage, London, UK.

Yu, H., Tweed, T., Al-Hussein, M. and Nasseri, R. (2009), "Development of lean model for house construction using value stream mapping", Journal of Construction Engineering and Management, Vol. 135 No. 8, pp. 782-790. 


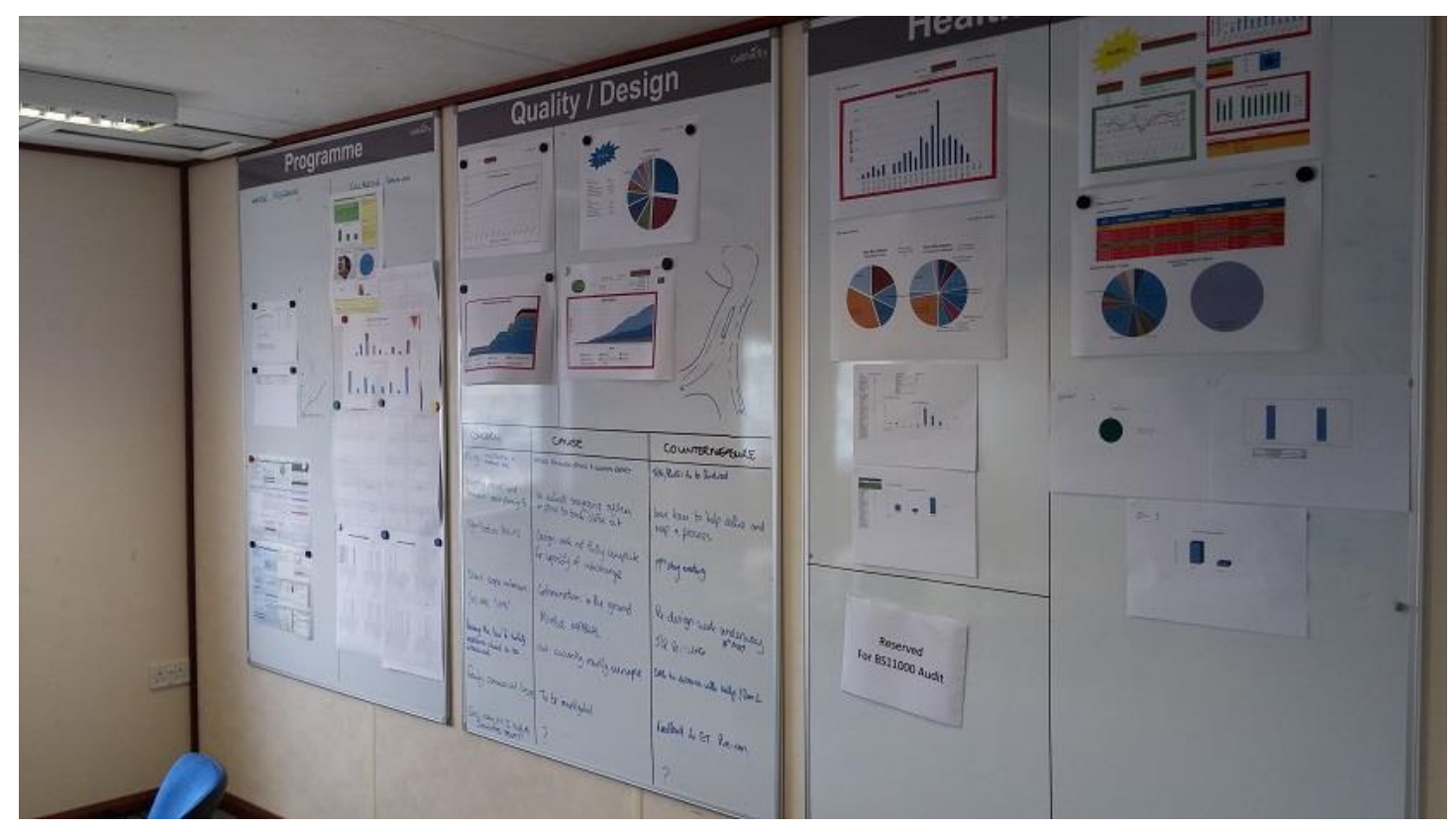

Fig 1. Meeting room (obeya) at Case 1 


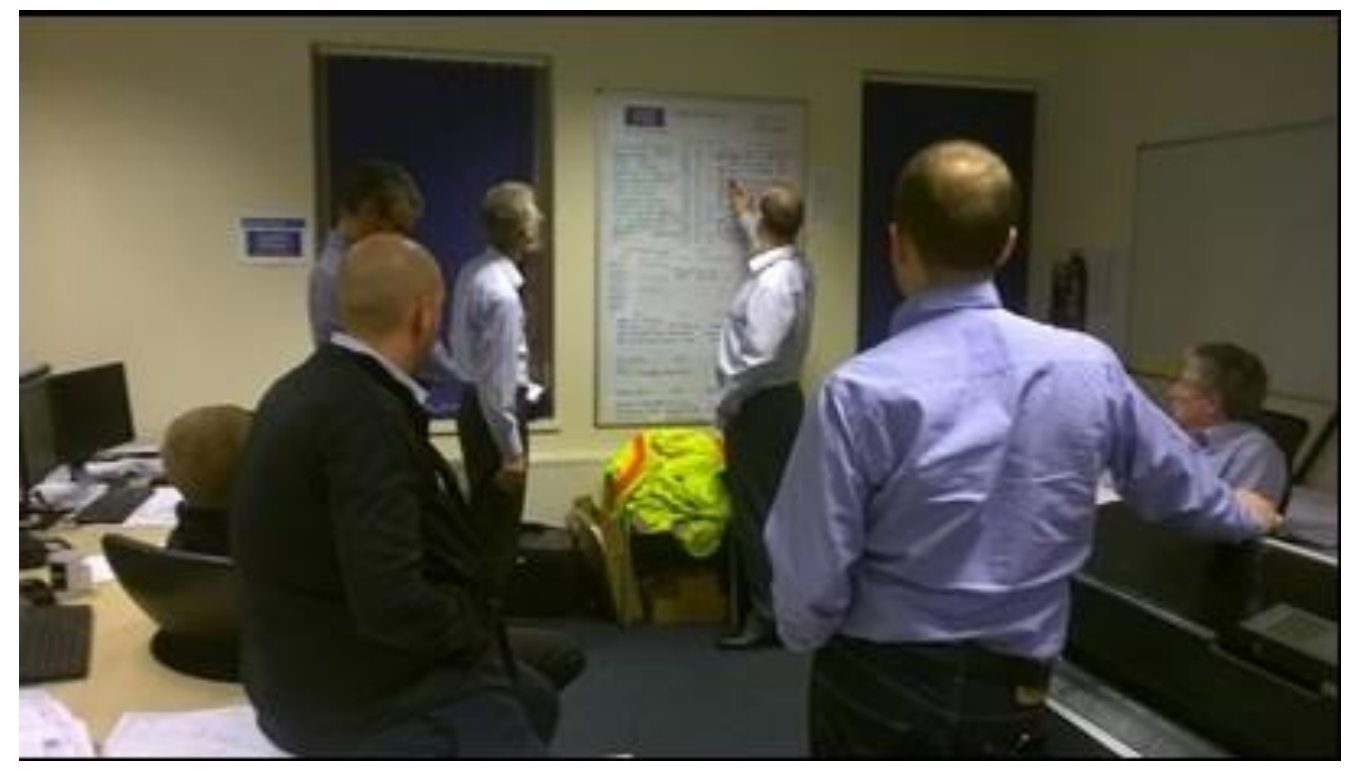

Fig 2. Design team's visual performance board at Case 2 


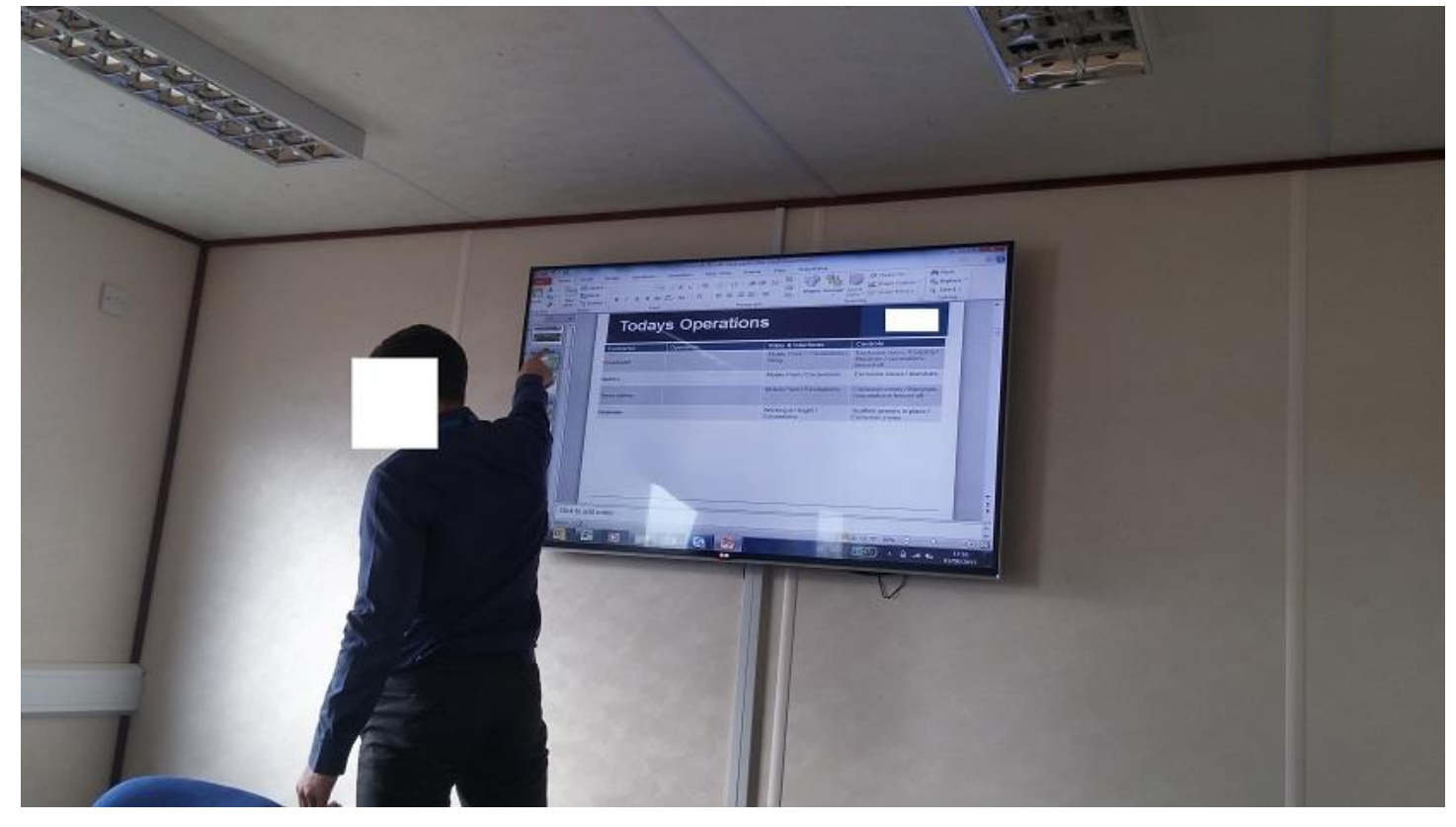

Fig 3. Preparation of BIM based Start of Shift Document showing subcontractors' work location at Case 3 


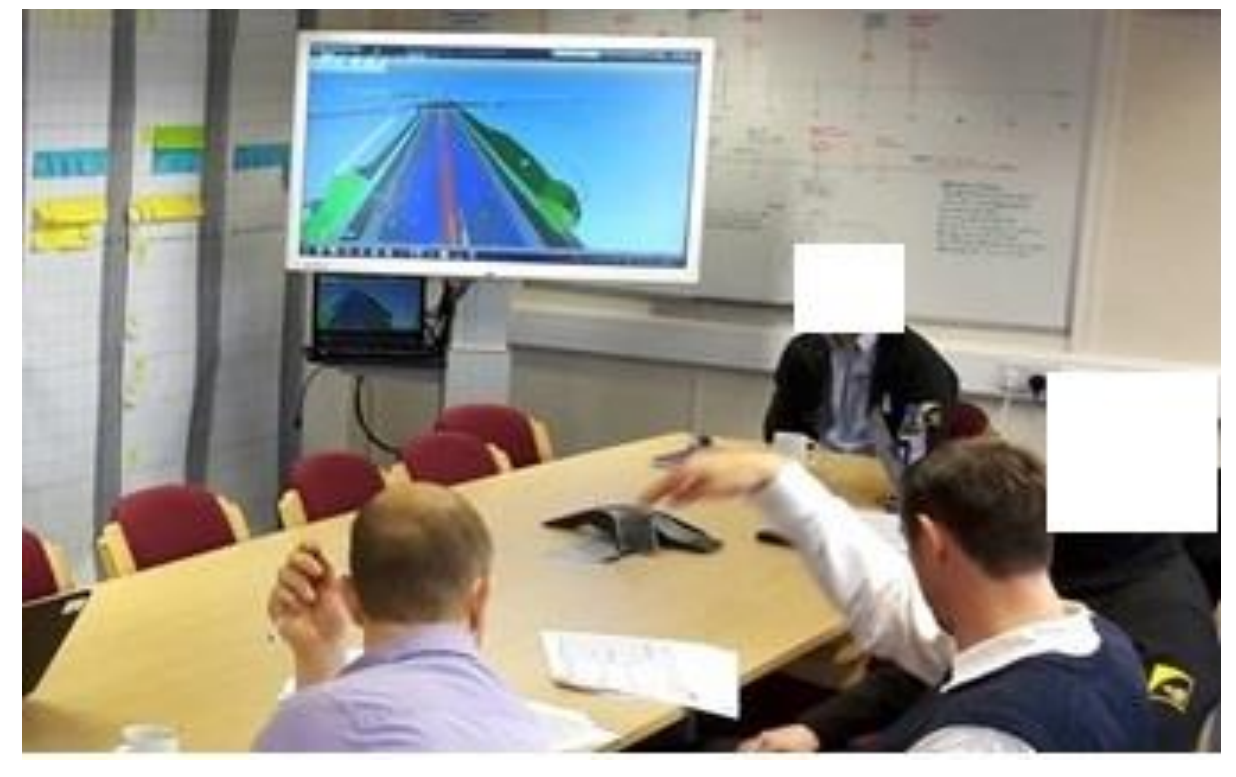

Fig 4. Use of BIM models in Collaborative Planning meetings at Case 4 


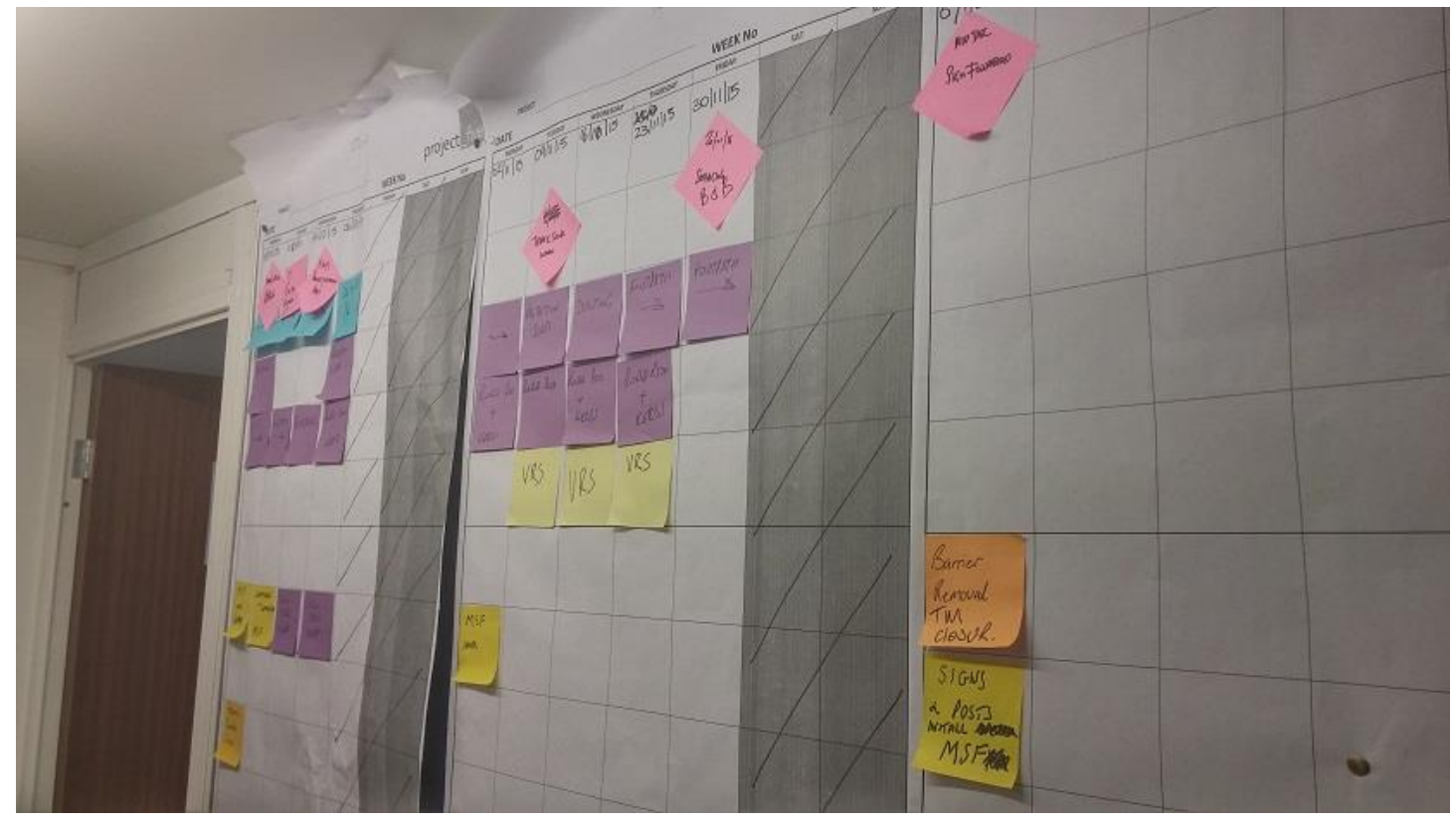

Fig 5. Use of Collaborative Planning boards at Case 5 


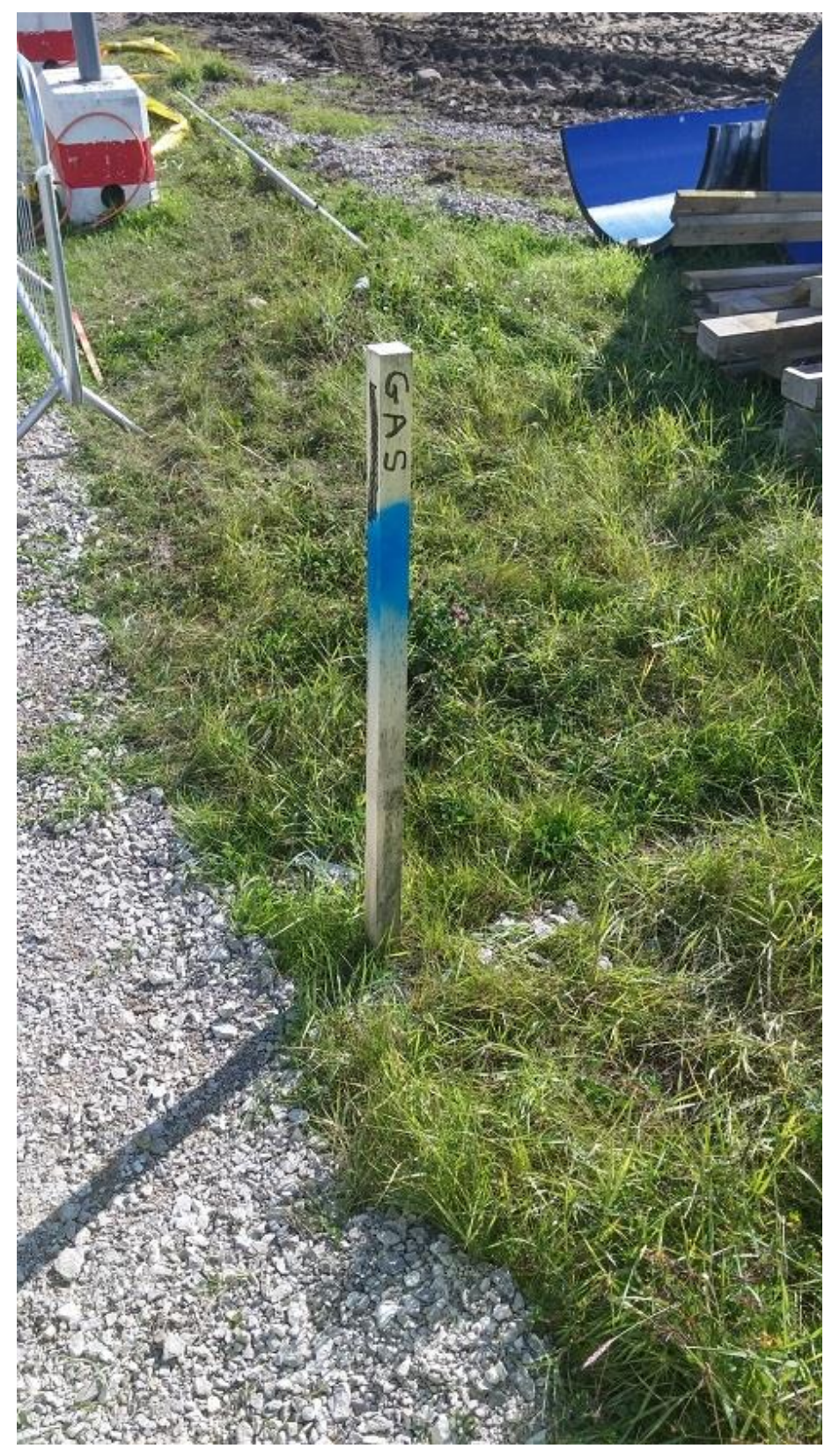

Fig 6. Marking underground utilities by using improvisational visualisation practices 


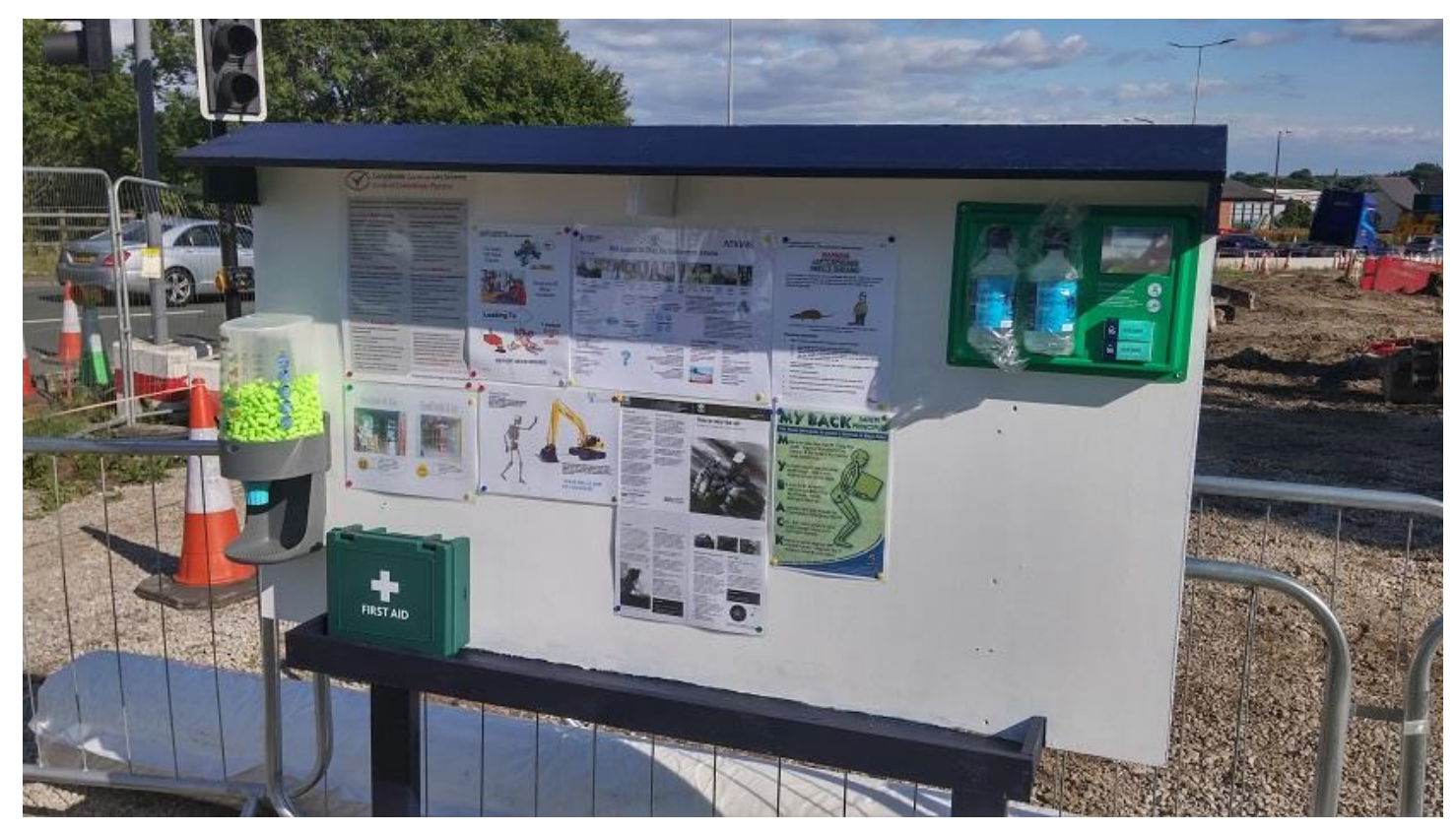

Fig 7. On-site health and safety boards 


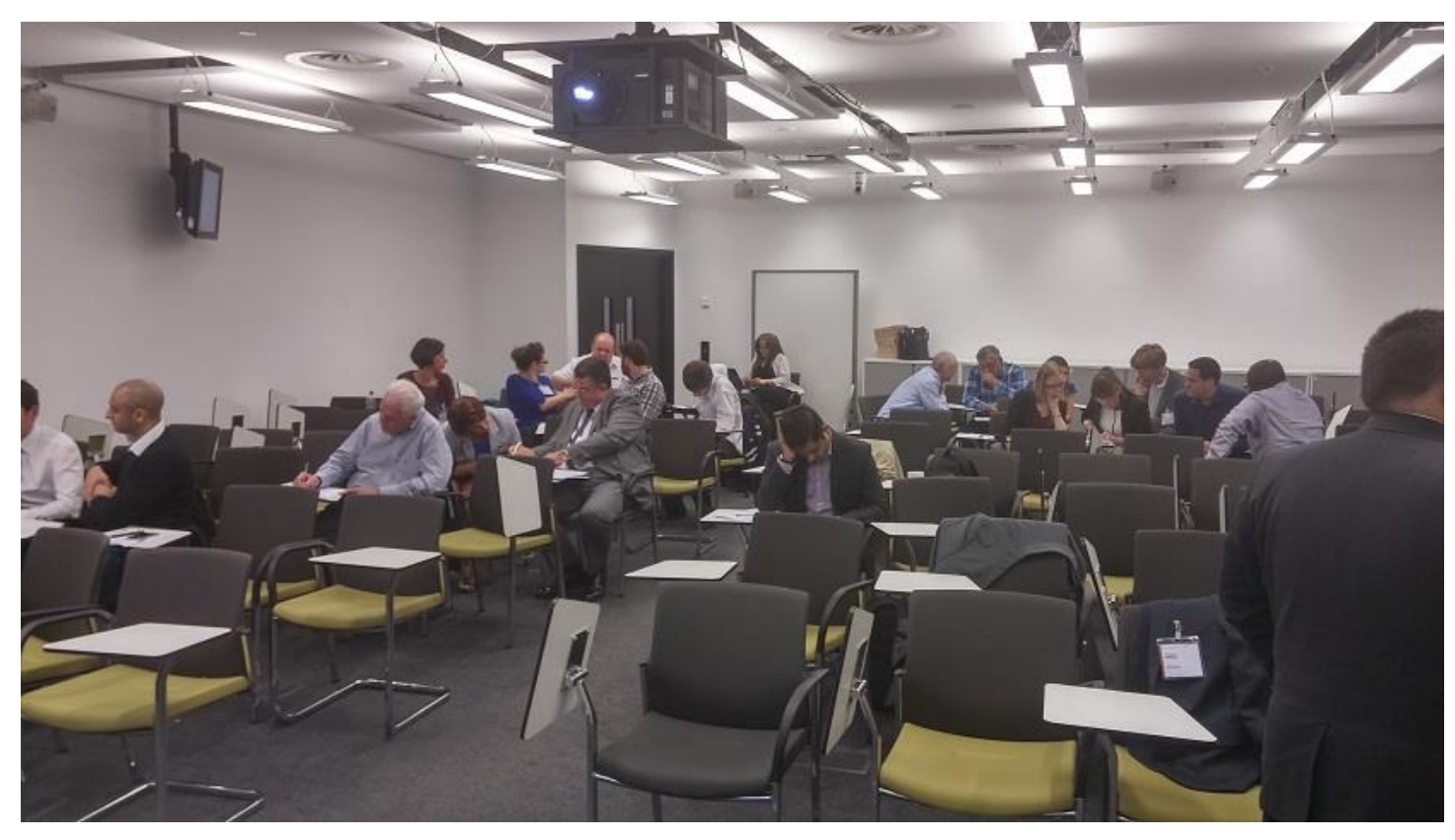

Fig 8. Visual Management focus groups 
Table 1 - Attributes of the Visited Case Sites

\begin{tabular}{|c|c|c|c|c|}
\hline $\begin{array}{l}\text { Case } \\
\text { No }\end{array}$ & Location & Project Cost & Project Scope & $\begin{array}{l}\text { Tier } 1 \text { (Main) Contractor } \\
\text { (s) }\end{array}$ \\
\hline 1 & $\begin{array}{l}\text { West } \\
\text { Midlands, } \\
\text { England }\end{array}$ & $\begin{array}{l}105 \text { million } \\
\text { British Pounds }\end{array}$ & $\begin{array}{lr}\text { New } & \text { motorway } \\
\text { construction } & \text { and } \\
\text { improvement. } & \text { Major } \\
\text { scheme. } & \end{array}$ & $\begin{array}{l}\text { Prominent } \\
\text { group with around } 5500 \\
\text { staff in the UK and } 80 \\
\text { years of operational } \\
\text { history. }\end{array}$ \\
\hline 2 & $\begin{array}{l}\text { Lancashire, } \\
\text { England }\end{array}$ & $\begin{array}{lr}202 & \text { million } \\
\text { British Pounds }\end{array}$ & $\begin{array}{l}\text { Upgrading the existing } \\
\text { motorway. } \\
\text { scheme. }\end{array}$ & $\begin{array}{l}\text { Joint venture of prominent } \\
\text { construction groups. }\end{array}$ \\
\hline 3 & $\begin{array}{l}\text { Cheshire, } \\
\text { England }\end{array}$ & $\begin{array}{lr}221 & \text { million } \\
\text { British Pounds }\end{array}$ & $\begin{array}{lr}\text { New } & \text { motorway } \\
\text { construction } & \text { and } \\
\text { improvement } & \text { with } \\
\text { seven new overpass } \\
\text { bridges. Major scheme. }\end{array}$ & $\begin{array}{l}\text { Prominent construction } \\
\text { group with around } 3300 \\
\text { staff and } 150 \text { years of } \\
\text { operational history. }\end{array}$ \\
\hline 4 & $\begin{array}{l}\text { North } \\
\text { Yorkshire, } \\
\text { England }\end{array}$ & $\begin{array}{lr}380 & \text { million } \\
\text { British } & \text { Pounds }\end{array}$ & $\begin{array}{l}\text { New three lane } \\
\text { motorway construction. } \\
\text { Major scheme. }\end{array}$ & $\begin{array}{l}\text { Joint venture of prominent } \\
\text { construction groups. }\end{array}$ \\
\hline 5 & $\begin{array}{l}\text { West } \\
\text { Yorkshire, } \\
\text { England }\end{array}$ & $\begin{array}{lr}6 & \text { million } \\
\text { British Pounds }\end{array}$ & $\begin{array}{l}\text { Motorway/ } \\
\text { roundabout } \\
\text { maintenance and } \\
\text { improvement. }\end{array}$ & $\begin{array}{l}\text { Prominent construction } \\
\text { group with around } 80000 \\
\text { staff worldwide and } 130 \\
\text { years of operational } \\
\text { history. }\end{array}$ \\
\hline
\end{tabular}


Table 2 - Realisation of the Data Collection Methods

\begin{tabular}{|c|c|c|c|c|c|c|}
\hline $\begin{array}{c}\text { Case } \\
\text { No }\end{array}$ & $\begin{array}{c}\text { Site } \\
\text { observations }\end{array}$ & $\begin{array}{c}\text { Site } \\
\text { photos }\end{array}$ & $\begin{array}{c}\text { Open-ended } \\
\text { interview } \\
\text { with business } \\
\text { improvement } \\
\text { managers }\end{array}$ & $\begin{array}{c}\text { Site } \\
\text { archives }\end{array}$ & $\begin{array}{c}\text { Informal } \\
\text { discussion with } \\
\text { construction } \\
\text { managers }\end{array}$ & $\begin{array}{c}\text { Questionnaire } \\
\text { with staff }\end{array}$ \\
\hline 1 & Yes & Yes & Yes & Yes & No & No \\
\hline 2 & Yes & Yes & Yes & Yes & Yes & Yes \\
\hline 3 & Yes & Yes & Yes & Yes & Yes & Yes \\
\hline 4 & Yes & Yes & Yes & Yes & Yes & No \\
\hline 5 & Yes & Yes & Yes & No & Yes & No \\
\hline
\end{tabular}


Table 3 - Details of the Case Visits and Interviews with the Business Improvement Managers

\begin{tabular}{|c|c|c|c|c|c|c|c|c|}
\hline $\begin{array}{l}\text { Case } \\
\text { No }\end{array}$ & $\begin{array}{l}\text { Number of } \\
\text { site visits }\end{array}$ & $\begin{array}{c}\text { Average } \\
\text { duration of } \\
\text { each site } \\
\text { visit } \\
\end{array}$ & $\begin{array}{l}\text { Number of } \\
\text { Interviews }\end{array}$ & $\begin{array}{c}\text { Average } \\
\text { duration of } \\
\text { interviews }\end{array}$ & $\begin{array}{l}\text { Background of } \\
\text { interviewees }\end{array}$ & $\begin{array}{l}\text { Recording } \\
\text { methods }\end{array}$ & Transcription & Interview focus \\
\hline 1 & 1 & 6 hours & 1 & 60 minutes & $\begin{array}{c}\text { Business } \\
\text { improvement } \\
\text { manager. } \\
\text { Chartered civil } \\
\text { engineer with } \\
\text { more than } 20 \\
\text { years of } \\
\text { experience. }\end{array}$ & Notes & Yes & $\begin{array}{cc}\text { - What are the } \\
\text { current VM } \\
\text { implementations } \\
\text { in your project? } \\
\text { What is your } \\
\text { perception of } \\
\text { VM? } \\
\text { - Are you aware } \\
\text { of more } \\
\text { advanced VM } \\
\text { concepts? } \\
\text { What kind of } \\
\text { problems are } \\
\text { you facing for } \\
\text { VM? } \\
\text { Can you suggest } \\
\text { any additional } \\
\text { VM } \\
\text { implementation } \\
\text { ideas? } \\
\end{array}$ \\
\hline 2 & 2 & 6 hours & 1 & 60 minutes & $\begin{array}{c}\text { Business } \\
\text { improvement } \\
\text { manager. MSc. in } \\
\text { construction } \\
\text { management. } 3 \\
\text { years of } \\
\text { experience at the } \\
\text { main } \\
\text { governmental } \\
\text { client and } 2 \text { years } \\
\text { of experience at } \\
\text { private } \\
\text { contractors in } \\
\text { highways. }\end{array}$ & Notes & Yes & $\begin{array}{c}\text { - What are the } \\
\text { current VM } \\
\text { implementations } \\
\text { in your project? } \\
\text { What is your } \\
\text { perception of } \\
\text { VM? } \\
\text { - Are you aware } \\
\text { of more } \\
\text { advanced VM } \\
\text { concepts? } \\
\text { What kind of } \\
\text { problems are } \\
\text { you facing for } \\
\text { VM? } \\
\text { Can you suggest } \\
\text { any additional } \\
\text { VM } \\
\text { implementation } \\
\text { ideas? }\end{array}$ \\
\hline 3 & 2 & 6 hours & 1 & 60 minutes & $\begin{array}{c}\text { Business } \\
\text { improvement } \\
\text { manager. Civil } \\
\text { engineer and } \\
\text { MSc. in } \\
\text { construction } \\
\text { management. } 3 \\
\text { years of } \\
\text { experience at } \\
\text { highways } \\
\text { contractors }\end{array}$ & Notes & Yes & $\begin{array}{c}\text { - What are the } \\
\text { current VM } \\
\text { implementations } \\
\text { in your project? } \\
\text { What is your } \\
\text { perception of } \\
\text { VM? } \\
\text { - Are you aware } \\
\text { of more } \\
\text { advanced VM } \\
\text { concepts? } \\
\text { What kind of } \\
\text { problems are } \\
\text { you facing for } \\
\text { VM? } \\
\text { Can you suggest } \\
\text { any additional } \\
\text { VM } \\
\text { implementation } \\
\text { ideas? }\end{array}$ \\
\hline 4 & 2 & 6 hours & 1 & 60 minutes & $\begin{array}{c}\text { Business } \\
\text { improvement } \\
\text { manager. Civil } \\
\text { engineer and } \\
\text { MSc. in } \\
\text { construction }\end{array}$ & Notes & Yes & $\begin{array}{l}\text { What are the } \\
\text { current VM } \\
\text { implementations } \\
\text { in your project? }\end{array}$ \\
\hline
\end{tabular}




\begin{tabular}{|c|c|c|c|c|c|c|c|c|}
\hline & & & & & $\begin{array}{l}\text { management with } \\
\text { more than } 10 \\
\text { years of } \\
\text { experience at } \\
\text { contractors in } \\
\text { highways }\end{array}$ & & & $\begin{array}{cc}\text { - What is your } \\
\text { perception of } \\
\text { VM? } \\
\text { - Are you aware } \\
\text { of more } \\
\text { advanced VM } \\
\text { concepts? } \\
\text { - What kind of } \\
\text { problems are } \\
\text { you facing for } \\
\text { VM? } \\
\text { - Can you suggest } \\
\text { any additional } \\
\text { VM } \\
\text { implementation } \\
\text { ideas? }\end{array}$ \\
\hline 5 & 1 & 6 hours & 1 & 60 minutes & $\begin{array}{c}\text { Business } \\
\text { improvement } \\
\text { manager. MSc. } \\
\text { in production } \\
\text { management. } 10 \\
\text { years of } \\
\text { experience at } \\
\text { manufacturing } \\
\text { companies. } 8 \\
\text { years of } \\
\text { experience at } \\
\text { highways } \\
\text { contractors }\end{array}$ & Notes & Yes & $\begin{array}{cc}\text { - } & \text { What are the } \\
\text { current VM } \\
\text { implementations } \\
\text { in your project? } \\
\text { What is your } \\
\text { perception of } \\
\text { VM? } \\
\text { - } \quad \text { Are you aware } \\
\text { of more } \\
\text { advanced VM } \\
\text { concepts? } \\
\text { What kind of } \\
\text { problems are } \\
\text { you facing for } \\
\text { VM? } \\
\text { Can you suggest } \\
\text { any additional } \\
\text { VM } \\
\text { implementation } \\
\text { ideas? }\end{array}$ \\
\hline
\end{tabular}


Table 4 - Professions of the Members of the Focus Groups

\begin{tabular}{|l|c|}
\hline Profession of Attendees & Count \\
\hline Academic & 12 \\
\hline Process improvement professionals & 6 \\
\hline Highways construction sector professional & 22 \\
\hline Total Number of Attendees & $\mathbf{4 0}$ \\
\hline
\end{tabular}


Table 5 - Visual Management on the Construction Field

\begin{tabular}{|c|c|c|c|c|c|}
\hline $\begin{array}{l}\text { Case } \\
\text { No }\end{array}$ & $\begin{array}{l}\text { Improvisational } \\
\text { Practices }\end{array}$ & Health and Safety & Quality & Programme & Housekeeping \\
\hline $\begin{array}{l}\text { Case } \\
1\end{array}$ & $\begin{array}{l}\text { - } \text { Marking } \\
\text { underground } \\
\text { utilities } \\
\text { - Marking } \\
\text { excavation } \\
\text { levels and } \\
\text { toes and tops } \\
\text { of slopes } \\
\text { Marking } \\
\text { level, } \\
\text { orientation, } \\
\text { position, and } \\
\text { type of } \\
\text { materials to } \\
\text { be } \\
\text { constructed } \\
\text { Quality } \\
\text { checks }\end{array}$ & $\begin{array}{ll}\text { - } & \text { Generic H\&S } \\
\text { signs } \\
\text { - } \mathrm{H \& S} \mathrm{mobile} \\
\text { boards } \\
\text { - } \text { Colour coded } \\
\text { equipment/tools } \\
\text { safety check } \\
\text { tags } \\
\text { - Goal posts } \\
\text { - Luminous } \\
\text { markers put on } \\
\text { barriers to avoid } \\
\text { human/vehicle } \\
\text { collisions. }\end{array}$ & & $\begin{array}{l}\text { Daily } \\
\text { meetings at } \\
\text { the site } \\
\text { office }\end{array}$ & 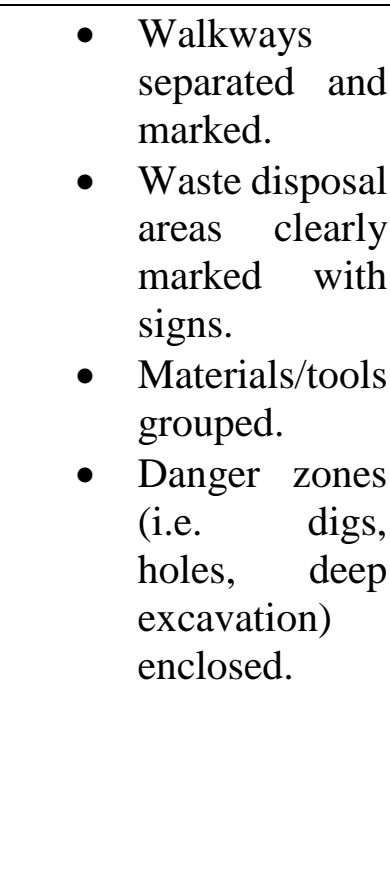 \\
\hline $\begin{array}{l}\text { Case } \\
2\end{array}$ & $\begin{array}{l}\text { Marking } \\
\text { underground } \\
\text { utilities } \\
\text { - Marking } \\
\text { excavation } \\
\text { levels and } \\
\text { toes and tops } \\
\text { of slopes } \\
\text { - Marking } \\
\text { level, } \\
\text { orientation, } \\
\text { position, and } \\
\text { type of } \\
\text { materials to } \\
\text { be } \\
\text { constructed } \\
\text { Quality } \\
\text { checks }\end{array}$ & 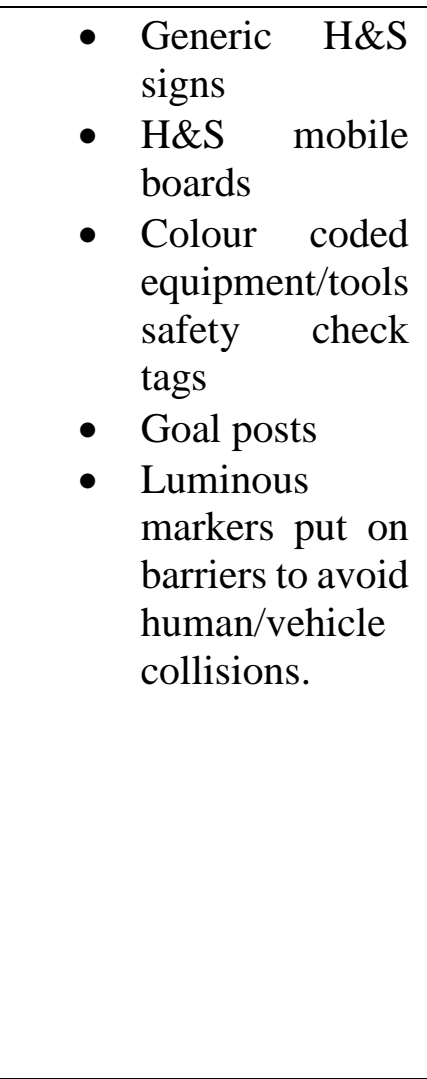 & $\begin{array}{l}\text { Basic } \\
\text { process } \\
\text { charts }\end{array}$ & $\begin{array}{l}\text { A visual } \\
\text { A3 sheet } \\
\text { that is } \\
\text { distributed } \\
\text { daily to the } \\
\text { site } \\
\text { managers }\end{array}$ & $\begin{array}{l}\text { - Walkways } \\
\text { separated and } \\
\text { marked. } \\
\text { - Waste disposal } \\
\text { areas clearly } \\
\text { marked with } \\
\text { signs. } \\
\text { - Materials/tools } \\
\text { grouped. } \\
\text { - Danger zones } \\
\text { (i.e. digs, } \\
\text { holes, deep } \\
\text { excavation) } \\
\text { enclosed. } \\
\text { A } \\
\text { programme is } \\
\text { tried to be } \\
\text { started by the } \\
\text { process } \\
\text { improvement } \\
\text { manager } \\
\text { (initial level) }\end{array}$ \\
\hline $\begin{array}{l}\text { Case } \\
3\end{array}$ & $\begin{array}{l}\text { Marking } \\
\text { underground } \\
\text { utilities }\end{array}$ & $\begin{array}{lll}\text { - } & \text { Generic } & \text { H\&S } \\
\text { signs } & \\
\text { - } & \text { H\&S } \\
\text { boards } & \text { mobile } \\
\end{array}$ & & $\begin{array}{l}\text { A } \\
\text { document } \\
\text { called Start } \\
\text { of Shift that }\end{array}$ & $\begin{array}{l}\text { Walkways } \\
\text { separated and } \\
\text { marked }\end{array}$ \\
\hline
\end{tabular}




\begin{tabular}{|c|c|c|c|c|c|}
\hline & 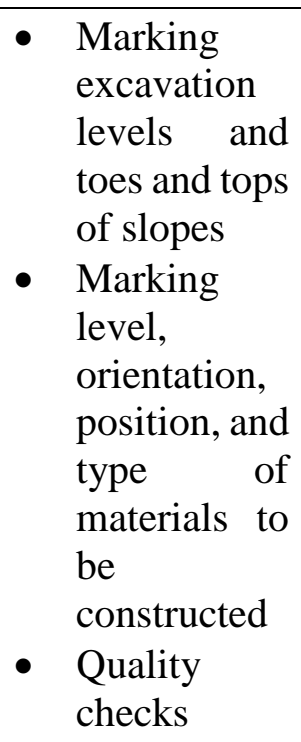 & $\begin{array}{l}\text { Top 5 safety } \\
\text { hazard boards } \\
\text { - Colour coded } \\
\text { equipment/tools } \\
\text { safety check } \\
\text { tags } \\
\text { - Goal posts } \\
\text { - Luminous } \\
\text { markers put on } \\
\text { barriers to avoid } \\
\text { human/vehicle } \\
\text { collisions. }\end{array}$ & & $\begin{array}{l}\text { is } \\
\text { distributed } \\
\text { daily to the } \\
\text { site } \\
\text { managers }\end{array}$ & 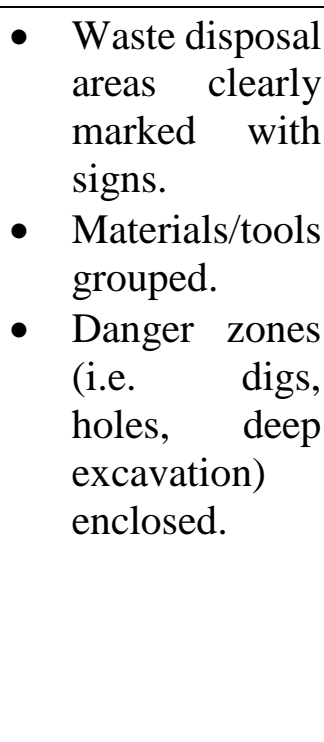 \\
\hline $\begin{array}{l}\text { Case } \\
4\end{array}$ & $\begin{array}{l}\text { - Marking } \\
\text { underground } \\
\text { utilities } \\
\text { Marking } \\
\text { excavation } \\
\text { levels and } \\
\text { toes and tops } \\
\text { of slopes } \\
\text { - Marking } \\
\text { level, } \\
\text { orientation, } \\
\text { position, and } \\
\text { type of } \\
\text { materials to } \\
\text { be } \\
\text { constructed } \\
\text { Quality } \\
\text { checks }\end{array}$ & 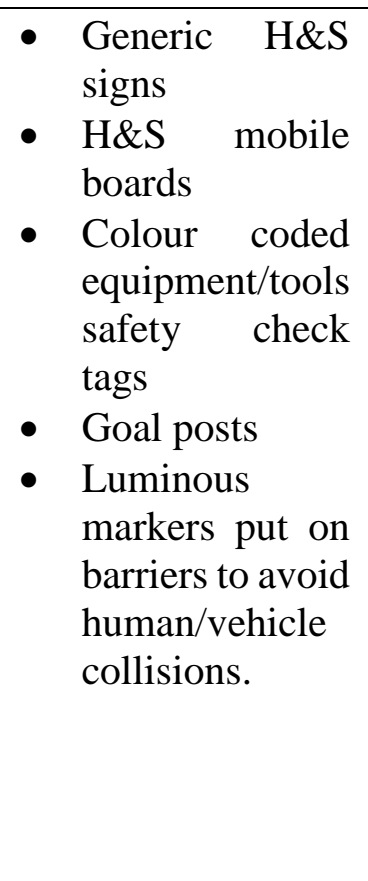 & $\begin{array}{l}\text { Basic } \\
\text { process } \\
\text { charts }\end{array}$ & $\begin{array}{l}\text { Daily } 4 \mathrm{C} \\
\text { meetings at } \\
\text { the site } \\
\text { office }\end{array}$ & 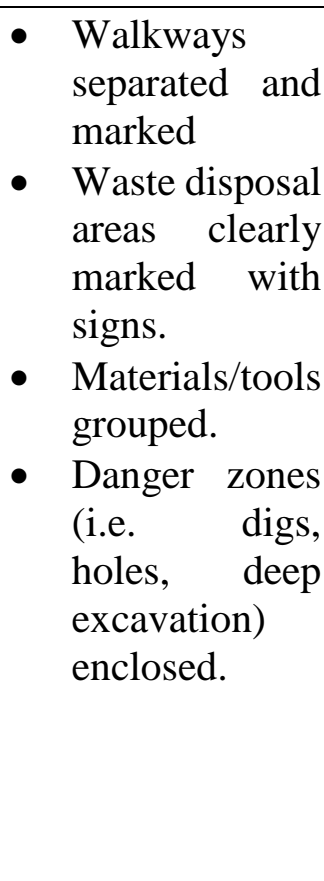 \\
\hline $\begin{array}{l}\text { Case } \\
5\end{array}$ & $\begin{array}{ll}\text { - } & \text { Marking } \\
\text { underground } \\
\text { utilities } \\
\text { - Marking } \\
\text { excavation } \\
\text { levels and } \\
\text { toes and tops } \\
\text { of slopes } \\
\text { Marking } \\
\text { level, } \\
\text { orientation, } \\
\text { position, and } \\
\text { type of } \\
\text { materials to }\end{array}$ & 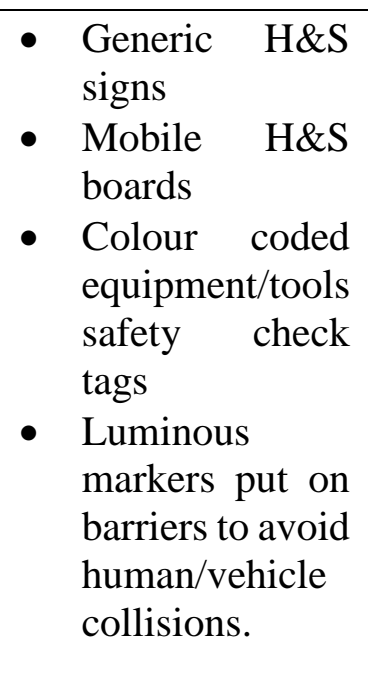 & $\begin{array}{l}\text { Basic } \\
\text { process } \\
\text { charts }\end{array}$ & $\begin{array}{l}\text { Daily } \\
\text { meetings at } \\
\text { the site } \\
\text { office }\end{array}$ & $\begin{array}{ll}\text { - } & \text { Walkways } \\
\text { separated and } \\
\text { marked } \\
\text { - Waste disposal } \\
\text { areas clearly } \\
\text { marked with } \\
\text { signs. } \\
\text { - Materials/tools } \\
\text { grouped. } \\
\text { Danger zones } \\
\text { (i.e. digs, } \\
\text { holes, deep } \\
\text { excavation) } \\
\text { enclosed. }\end{array}$ \\
\hline
\end{tabular}




\begin{tabular}{|l|l|l|l|l|}
\hline $\begin{array}{l}\text { be } \\
\text { constructed } \\
\text { Quality } \\
\text { checks }\end{array}$ & & & & $\begin{array}{l}\text { A } \\
\text { programme is } \\
\text { tried to be } \\
\text { started by the } \\
\text { process } \\
\text { improvement } \\
\text { manager } \\
\text { (initial level) }\end{array}$ \\
\hline
\end{tabular}


Table 6- VM Questionnaire Findings

\begin{tabular}{|c|c|c|c|c|c|c|}
\hline $\begin{array}{l}\text { Case } \\
\text { No }\end{array}$ & Occupation & $\begin{array}{l}\text { How often } \\
\text { do you use } \\
\text { the visual } \\
\text { performance } \\
\text { boards? }\end{array}$ & $\begin{array}{l}\text { How do } \\
\text { you find } \\
\text { the } \\
\text { general } \\
\text { site/ } \\
\text { compound } \\
\text { order? }\end{array}$ & $\begin{array}{c}\text { How do you } \\
\text { find the } \\
\text { current } \\
\text { level of } \\
\text { visual } \\
\text { information } \\
\text { shared in } \\
\text { the } \\
\text { construction } \\
\text { field with } \\
\text { the field } \\
\text { personnel? }\end{array}$ & $\begin{array}{l}\text { What kind of } \\
\text { information } \\
\text { should be visually } \\
\text { shared more with } \\
\text { the field personnel } \\
\text { in the future? }\end{array}$ & $\begin{array}{c}\text { How often } \\
\text { do you use } \\
\text { the BIM } \\
\text { system in } \\
\text { your } \\
\text { operations }\end{array}$ \\
\hline 2 & $\begin{array}{c}\text { Civil } \\
\text { engineer }\end{array}$ & Frequently & Average & $\begin{array}{c}\text { Below } \\
\text { average }\end{array}$ & $\begin{array}{c}\text { Schedule/Programme } \\
\text { Related, Quality } \\
\text { Related, Process } \\
\text { Related }\end{array}$ & Rarely \\
\hline 2 & $\begin{array}{c}\text { Civil } \\
\text { engineer }\end{array}$ & Frequently & Average & $\begin{array}{l}\text { Below } \\
\text { average }\end{array}$ & $\begin{array}{l}\text { Quality Related, } \\
\text { Process Related }\end{array}$ & Rarely \\
\hline 2 & Foreman & Occasionally & Average & Average & $\begin{array}{c}\text { Schedule/Programme } \\
\text { Related, Quality } \\
\text { Related }\end{array}$ & Never \\
\hline 2 & $\begin{array}{c}\text { Senior } \\
\text { traffic safety } \\
\text { controller } \\
\end{array}$ & Frequently & $\begin{array}{l}\text { Below } \\
\text { average }\end{array}$ & Average & $\begin{array}{l}\text { Quality Related, } \\
\text { Process Related }\end{array}$ & Rarely \\
\hline 2 & Foreman & Occasionally & $\begin{array}{l}\text { Below } \\
\text { average }\end{array}$ & Average & $\begin{array}{c}\text { Schedule/Programme } \\
\text { Related }\end{array}$ & Never \\
\hline 2 & $\begin{array}{l}\text { General } \\
\text { foreman }\end{array}$ & Occasionally & $\begin{array}{c}\text { Above } \\
\text { average }\end{array}$ & $\begin{array}{l}\text { Below } \\
\text { average }\end{array}$ & $\begin{array}{c}\text { Schedule/Programme } \\
\text { Related, Quality } \\
\text { Related, Process } \\
\text { Related } \\
\end{array}$ & Never \\
\hline 2 & $\begin{array}{c}\text { Site } \\
\text { supervisor }\end{array}$ & Frequently & Average & Average & $\begin{array}{c}\text { Schedule/Programme } \\
\text { Related, Process } \\
\text { Related }\end{array}$ & Never \\
\hline 2 & $\begin{array}{c}\text { Civil } \\
\text { engineer }\end{array}$ & Frequently & Average & Intensive & $\begin{array}{c}\text { Schedule/Programme } \\
\text { Related, Quality } \\
\text { Related, Cost } \\
\text { Related }\end{array}$ & Rarely \\
\hline 2 & $\begin{array}{c}\text { Site } \\
\text { supervisor }\end{array}$ & Frequently & Average & Average & $\begin{array}{c}\text { Schedule/Programme } \\
\text { Related, Quality } \\
\text { Related, Cost } \\
\text { Related }\end{array}$ & Rarely \\
\hline 2 & $\begin{array}{c}\text { Traffic } \\
\text { management }\end{array}$ & Occasionally & $\begin{array}{l}\text { Below } \\
\text { average }\end{array}$ & Average & $\begin{array}{c}\text { Schedule/Programme } \\
\text { Related, Process } \\
\text { Related }\end{array}$ & Rarely \\
\hline 2 & $\begin{array}{l}\text { Health and } \\
\text { safety } \\
\text { officer }\end{array}$ & Frequently & $\begin{array}{c}\text { Above } \\
\text { average }\end{array}$ & $\begin{array}{c}\text { Below } \\
\text { average }\end{array}$ & $\begin{array}{c}\text { Schedule/Programme } \\
\text { Related, Quality } \\
\text { Related, Process } \\
\text { Related }\end{array}$ & Rarely \\
\hline 3 & Engineer & Frequently & $\begin{array}{l}\text { Above } \\
\text { average }\end{array}$ & Average & $\begin{array}{c}\text { Schedule/Programme } \\
\text { Related, Quality } \\
\text { Related, Health and }\end{array}$ & Rarely \\
\hline
\end{tabular}




\begin{tabular}{|c|c|c|c|c|c|c|}
\hline & & & & & $\begin{array}{l}\text { Safety Related, } \\
\text { Process Related }\end{array}$ & \\
\hline 3 & Engineer & Frequently & Average & $\begin{array}{c}\text { Below } \\
\text { average }\end{array}$ & Process Related & Rarely \\
\hline 3 & Engineer & Occasionally & Average & $\begin{array}{l}\text { Below } \\
\text { average }\end{array}$ & $\begin{array}{c}\text { Schedule/Programme } \\
\text { Related, Quality } \\
\text { Related, Health and } \\
\text { Safety Related, } \\
\text { Process Related, } \\
\text { Environmental, } \\
\text { Human Resources } \\
\text { Related, Cost } \\
\text { Related }\end{array}$ & Rarely \\
\hline 3 & $\begin{array}{l}\text { Community } \\
\text { engagement }\end{array}$ & Occasionally & Average & Average & $\begin{array}{c}\text { Process Related, } \\
\text { Environmental, } \\
\text { Human Resources } \\
\text { Related, Cost } \\
\text { Related }\end{array}$ & Never \\
\hline 3 & Planning & Occasionally & Average & Intensive & $\begin{array}{c}\text { Schedule/Programme } \\
\text { Related, Quality } \\
\text { Related }\end{array}$ & Occasionally \\
\hline 3 & $\begin{array}{c}\text { Project } \\
\text { management }\end{array}$ & Frequently & $\begin{array}{c}\text { Below } \\
\text { average }\end{array}$ & $\begin{array}{c}\text { Below } \\
\text { average }\end{array}$ & $\begin{array}{l}\text { Schedule/Programme } \\
\text { Related, Health and } \\
\text { Safety Related, } \\
\text { Process Related, } \\
\text { Cost Related }\end{array}$ & Occasionally \\
\hline 3 & $\begin{array}{l}\text { Health and } \\
\text { safety } \\
\text { officer }\end{array}$ & Frequently & $\begin{array}{c}\text { Below } \\
\text { average }\end{array}$ & $\begin{array}{l}\text { Below } \\
\text { average }\end{array}$ & $\begin{array}{c}\text { Schedule/Programme } \\
\text { Related, Quality } \\
\text { Related, Health and } \\
\text { Safety Related, } \\
\text { Process Related, } \\
\text { Environmental, } \\
\text { Human Resources } \\
\text { Related, Cost } \\
\text { Related }\end{array}$ & Rarely \\
\hline 3 & Foreman & Frequently & $\begin{array}{c}\text { Below } \\
\text { average }\end{array}$ & Average & $\begin{array}{c}\text { Schedule/Programme } \\
\text { Related, Quality } \\
\text { Related, Cost } \\
\text { Related }\end{array}$ & Never \\
\hline 3 & Foreman & Frequently & Average & $\begin{array}{c}\text { Below } \\
\text { average }\end{array}$ & $\begin{array}{c}\text { Schedule/Programme } \\
\text { Related, Quality } \\
\text { Related, Cost } \\
\text { Related }\end{array}$ & Never \\
\hline
\end{tabular}


Table 7 - Focus Group Study Findings

\begin{tabular}{|c|c|c|c|c|}
\hline $\begin{array}{l}\text { Gro } \\
\text { up } \\
\text { No }\end{array}$ & $\begin{array}{l}\text { Business } \\
\text { Problem }\end{array}$ & $\begin{array}{l}\text { Problem } \\
\text { Analysis (Root } \\
\text { cause) }\end{array}$ & $\begin{array}{l}\text { Proposed } \\
\text { Solution }\end{array}$ & $\begin{array}{l}\text { Implementatio } \\
\text { n Plan }\end{array}$ \\
\hline 1 & $\begin{array}{l}\text { - The } \\
\text { unneces } \\
\text { sary } \\
\text { duplicat } \\
\text { ion of } \\
\text { data and } \\
\text { informa } \\
\text { tion } \\
\text { generate } \\
\text { d within } \\
\text { the } \\
\text { industry } \\
\text {. }\end{array}$ & $\begin{array}{ll}\text { Related } \\
\text { with } \\
\text { organis } \\
\text { ational } \\
\text { structur } \\
\text { es and } \\
\text { procedu } \\
\text { res. }\end{array}$ & $\begin{array}{l}\text { Make relevant } \\
\text { information/p } \\
\text { rocesses } \\
\text { available to } \\
\text { similar } \\
\text { organisations. }\end{array}$ & $\begin{array}{l}\text { - A } \\
\text { benchm } \\
\text { arking } \\
\text { event in } \\
\text { which } \\
\text { differen } \\
\mathrm{t} \\
\text { industry } \\
\text { leaders } \\
\text { are } \\
\text { involve } \\
\text { d to } \\
\text { identify } \\
\text { the } \\
\text { points } \\
\text { of } \\
\text { collabor } \\
\text { ation to } \\
\text { avoid } \\
\text { the } \\
\text { duplicat } \\
\text { ion } \\
\text { waste. }\end{array}$ \\
\hline 2 & $\begin{array}{l}\text { - The } \\
\text { contract } \\
\text { ual } \\
\text { structur } \\
\text { e may } \\
\text { hinder } \\
\text { the } \\
\text { further } \\
\text { develop } \\
\text { ment of } \\
\text { lean and } \\
\text { VM for } \\
\text { the } \\
\text { compan } \\
\text { ies. } \\
\text { Lack of } \\
\text { employ } \\
\text { ee } \\
\text { engage } \\
\text { ment } \\
\text { Lack of } \\
\text { readily }\end{array}$ & 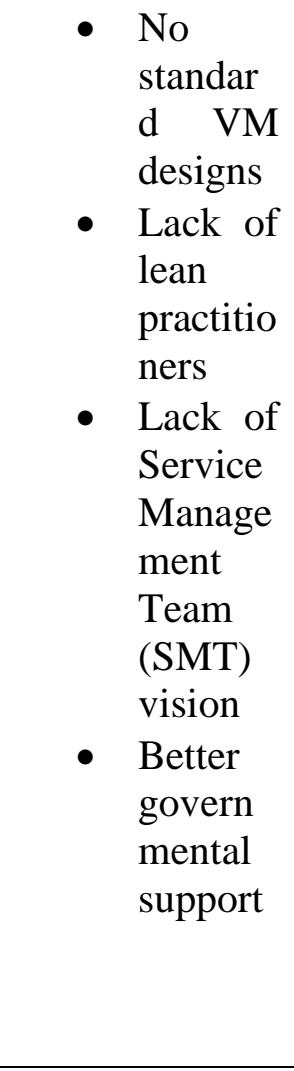 & $\begin{array}{l}\text { - Get your } \\
\text { company's } \\
\text { SMT } \\
\text { involved } \\
\text { - Recruitment } \\
\text { of the right } \\
\text { people for the } \\
\text { job with lean } \\
\text { and VM } \\
\text { - Use } \\
\text { training the } \\
\text { pyramid for } \\
\text { people with } \\
\text { different } \\
\text { levels of lean } \\
\text { and VM } \\
\text { knowledge } \\
\text { (i.e } \\
\text { practitioners, } \\
\text { green belts, } \\
\text { black belts } \\
\text { etc) }\end{array}$ & $\begin{array}{l}\text { - Service } \\
\text { Manage } \\
\text { ment } \\
\text { Team } \\
\text { (SMT) } \\
\text { to drive } \\
\text { VM } \\
\text { - Employ } \\
\text { lean } \\
\text { champi } \\
\text { ons } \\
\text { Better } \\
\text { training } \\
\text { on lean } \\
\text { and VM } \\
\text { Extend } \\
\text { VM to } \\
\text { producti } \\
\text { on areas } \\
\text { to } \\
\text { include } \\
\text { the 5S, }\end{array}$ \\
\hline
\end{tabular}




\begin{tabular}{|c|c|c|c|c|}
\hline & $\begin{array}{l}\text { availabl } \\
\text { e } \\
\text { informa } \\
\text { tion - } \\
\text { show } \\
\text { the line } \\
\text { of sight } \\
\text { for the } \\
\text { workfor } \\
\text { ce } \\
\text { The } \\
\text { large } \\
\text { amount } \\
\text { of waste } \\
\text { in our } \\
\text { process } \\
\text { es and } \\
\text { its } \\
\text { ownersh } \\
\text { ip }\end{array}$ & & $\begin{array}{l}\text { - Get a pilot } \\
\text { VM } \\
\text { implementati } \\
\text { on area to } \\
\text { show the } \\
\text { benefits. }\end{array}$ & $\begin{array}{l}\text { kanban, } \\
\text { poka- } \\
\text { yokes } \\
\text { etc. }\end{array}$ \\
\hline 3 & $\begin{array}{l}\text { - Not } \\
\text { showing } \\
\text { the big } \\
\text { picture/t } \\
\text { argets in } \\
\text { our VM } \\
\text { efforts }\end{array}$ & 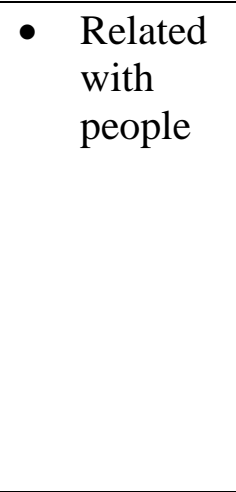 & $\begin{array}{l}\text { - Show the real } \\
\text { vision } \\
\text { - Add project } \\
\text { targets to your } \\
\text { VM boards } \\
\text { - Show the } \\
\text { work streams } \\
\text { together with } \\
\text { their } \\
\text { interactions. }\end{array}$ & \\
\hline 4 & 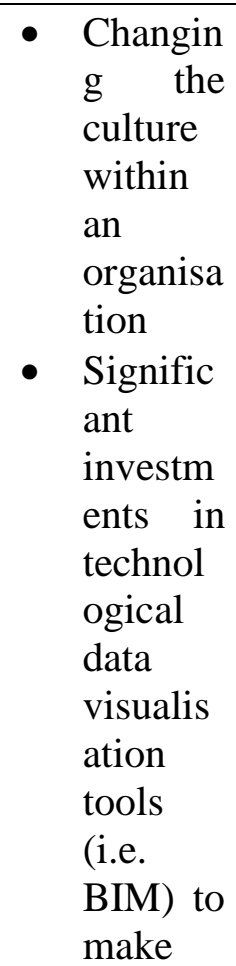 & $\begin{array}{l}\text { - Lack of } \\
\text { training } \\
\text { and } \\
\text { training } \\
\text { funding } \\
\text { - Resista } \\
\text { nce to } \\
\text { change } \\
\text { - Abunda } \\
\text { nce of } \\
\text { differen } \\
\text { t } \\
\text { termino } \\
\text { logy } \\
\text { and } \\
\text { languag } \\
\text { e. It is } \\
\text { confusi } \\
\text { ng }\end{array}$ & 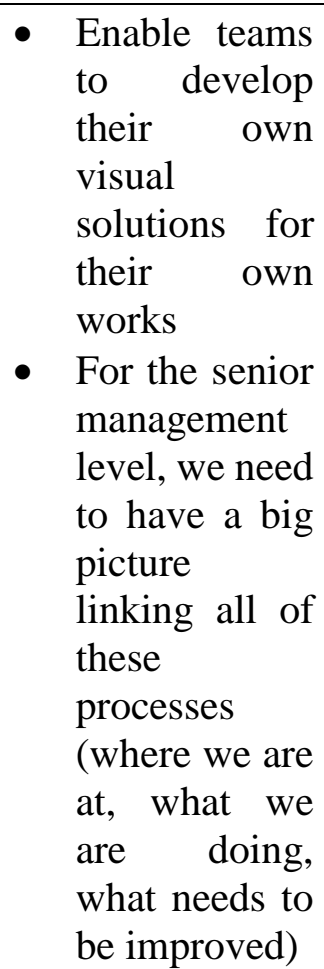 & $\begin{array}{l}\text { - } \text { Show } \\
\text { cost vs } \\
\text { return to } \\
\text { justify } \\
\text { the } \\
\text { benefits } \\
\text { of Lean } \\
\text { and VM }\end{array}$ \\
\hline
\end{tabular}




\begin{tabular}{|c|c|c|c|c|}
\hline & $\begin{array}{l}\text { data } \\
\text { accessib } \\
\text { le to all }\end{array}$ & & & \\
\hline 5 & $\begin{array}{l}\text { - Minima } \\
1 \\
\text { visibilit } \\
\text { y of } \\
\text { perform } \\
\text { ance at a } \\
\text { granular } \\
\text { level } \\
\text { - We } \\
\text { collate } \\
\text { informa } \\
\text { tion for } \\
\text { the } \\
\text { benefit } \\
\text { of the } \\
\text { client's } \\
\text { needs } \\
\text { rather } \\
\text { than for } \\
\text { our own } \\
\text { benefits }\end{array}$ & 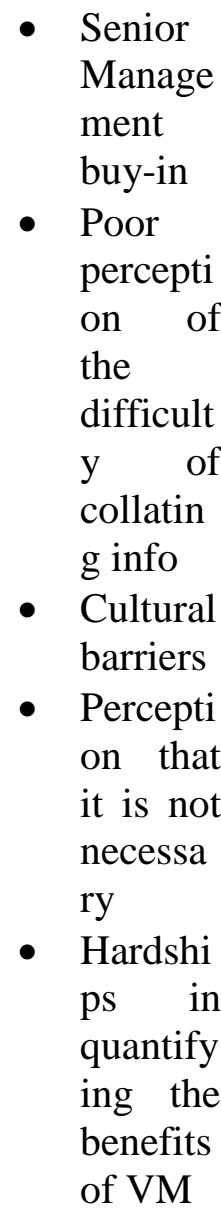 & $\begin{array}{l}\text { - Introduce } \\
\text { smart } \\
\text { technologies } \\
\text { to the teams } \\
\text { (i.e. BIM) } \\
\text { - Introduce } \\
\text { visual boards } \\
\text { and identify } \\
\text { VM board } \\
\text { owners } \\
\text { Capture } \\
\text { lessons learnt }\end{array}$ & 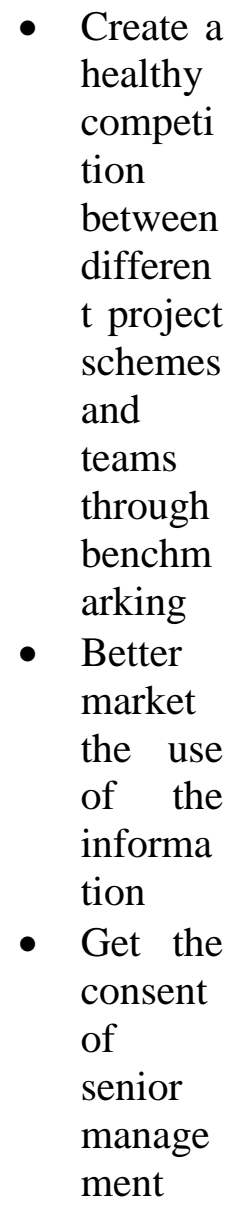 \\
\hline 6 & 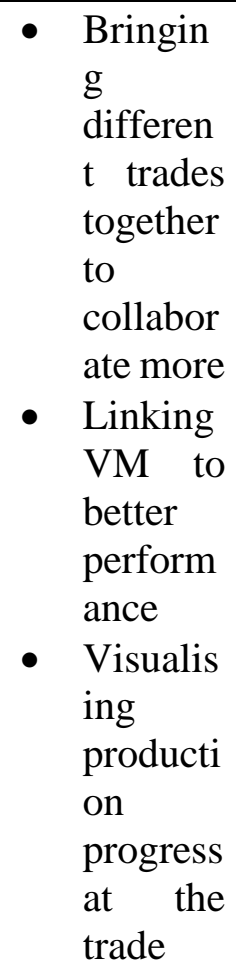 & $\begin{array}{l}\text { - Getting } \\
\text { people } \\
\text { focused } \\
\text { on the } \\
\text { Lean } \\
\text { and VM } \\
\text { initiativ } \\
\text { e }\end{array}$ & $\begin{array}{l}\text { - Colour code } \\
\text { different work } \\
\text { trade areas, } \\
\text { tools, gadgets } \\
\text { etc. }\end{array}$ & $\begin{array}{l}\text { - } \text { Organis } \\
\text { e VM } \\
\text { sessions } \\
\text { among } \\
\text { differen } \\
\mathrm{t} \text { work } \\
\text { trades } \\
\text { for } \\
\text { further } \\
\text { VM } \\
\text { improve } \\
\text { ments } \\
\text { and } \\
\text { focus. }\end{array}$ \\
\hline
\end{tabular}




\begin{tabular}{|c|c|c|c|c|}
\hline & $\begin{array}{l}\text { interfac } \\
\mathrm{e}\end{array}$ & & & \\
\hline 7 & 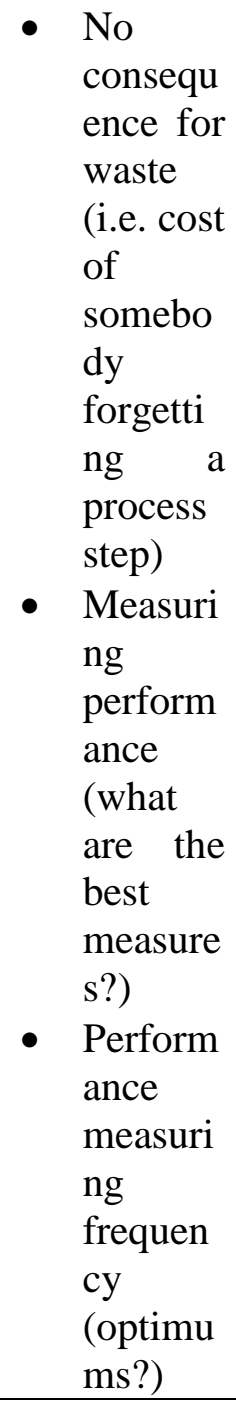 & $\begin{array}{l}\text { - } \text { Related } \\
\text { with } \\
\text { people, } \\
\text { plant } \\
\text { and } \\
\text { environ } \\
\text { ment }\end{array}$ & $\begin{array}{l}\text { - Industry audit } \\
\text { for VM } \\
\text { - Identifying } \\
\text { improvement } \\
\text { plans at the } \\
\text { end of the } \\
\text { audit } \\
\text { - Collecting } \\
\text { VM ideas on } \\
\text { site } \\
\text { Come up with } \\
\text { a way to } \\
\text { visually } \\
\text { demonstrate } \\
\text { the } \\
\text { consequences } \\
\text { of waste. } \\
\text { Devise } \\
\text { visual system } \\
\text { (board) on } \\
\text { which people } \\
\text { can } \\
\text { capture/recor } \\
\text { d the waste in } \\
\text { their } \\
\text { processes }\end{array}$ & $\begin{array}{l}\text { - Create } \\
\text { an } \\
\text { industry } \\
\text { VM } \\
\text { audit } \\
\text { - Identify } \\
\text { improve } \\
\text { ment } \\
\text { ideas } \\
\text { - Share } \\
\text { learning } \\
\text { and best } \\
\text { practice } \\
\text { s with } \\
\text { other } \\
\text { people } \\
\text { to } \\
\text { inspire } \\
\text { them } \\
\text { Work } \\
\text { with } \\
\text { clarity }\end{array}$ \\
\hline
\end{tabular}

